\section{V - BIBLIOGRAFIA CITADA}

BOURGOIGNE, Thierry. Introduction. in Revue Internationale de Droit Compare, vol. 513, 1982, p. 03.

CRANSTON, Ross. Principles of banking law. Oxford, Clarendon Press, 1997.

DALL'AGNOLJUNIOR, Antonio Janyr; Direito do consumidor e serviços bancários e financeiros - aplicação do CDC nas atividades bancárias Revista do Direito do Consumidor, vol. 15, 1998, p. 27.

FORTUNA, Eduardo. Mercado Financeiro produtos e servicos. Rio de Janeiro, Qualitymark Editora Ltda., 1992.

GREEWALD, Douglas. Dictionnnaire economique, Librairie General de Droit et Jurisprudence Paris, 1993

LANTIN, Barbara \& WOODROFFE, Geoffrey Service please, National Consume Council, 1981.

LEWIS, Russel. The new service society, Longman Group Limited, 1973.

LOPES, José Reinaldo de Lima. Responsabi lidade civil do fabricante $e$ a defesa do consumidor. São Paulo, Editora Revista dos Tribunais, 1992
MARQUES, Cláudia Lima. Contratos bancários em tempos pós-modernos - primeiras reflexôes. In Revista do Direito do Consumidor, vol. 25, 1998, p. 19.

MARTINS-COSTA, Judith. Sistema $e$ clausula geral, Tese de Doutorado, Sao Paulo, USP, 1996.

NATIONAL CONSUMER COUNCIL. Banking services and the consumer, Londres, Methuen \& $\mathrm{Co}$ Ltd., 1983.

RAMSAY, Iain. Consumer Protection: text and materials. Londres, Weidenfeld and Nicolson, 1989.

SCOTT, Hall \& WELLONS, Philip. International Finance. Nova Iorque, Foundation Press, 1998.

TIMM, Luciano Benetti. Da prestação de servicos. Porto Alegre, Sintese, 1998.

WALD, Arnold; O direito do consumidor e suas repercussónes em relação às instituições financeiras. Revista dos Tribunais, vol. 66, 1991, p. 12.

\title{
O direito ao livre desenvolvimento da personalidade na Alemanha e possibilidades de sua aplicação no Direito privado brasileiro*
}

\author{
Marcos de Campos Ludwig \\ Mestrando em Direito Privado pela UFRGS \\ Pesquisador-bolsista da Fundação CAPES
}

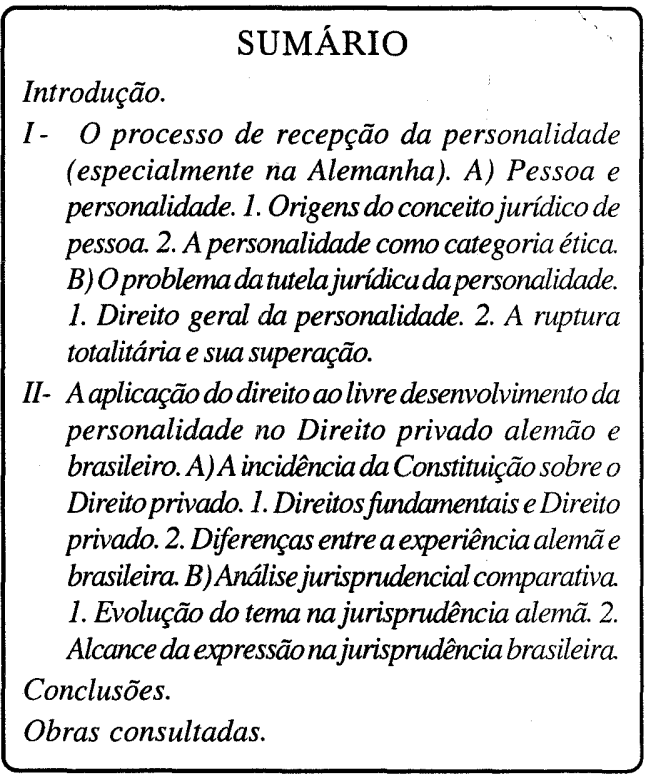

\section{INTRODUÇÃO}

O direito ao livre desenvolvimento da personalidade está expressamente consagrado na Alemanha pelo art. 2, 1, da Lei Fundamental $^{1}$, tendo exercido, desde o alvorecer do pósguerra, considerável influência sobre as relações jusprivadas, graças à perspectiva constitucional adotada e trabalhada pelos tribunais maiores daquele país. Assumiu papel basilar nesse sentido, desde sua instituição em 1951, a Corte Constitucional germânica (Bundesverfassungsgericht-BVerfG).

Tal evolução jurisprudencial, como veremos, não ocorreu por acaso: escudavam-na vários séculos de doutrina teológica, filosófica $\mathrm{e}$ jurídica, que culminaram na elaboração do que veio a ser chamado, já no final do século XIX, de Direito geral da personalidade. Essa teoria,

* Este artigo é uma versão retrabalhada da monografia escrita para a disciplina de Teoria Geral do Direito Privado, ministrada pela professora Dra. Judith Martins-Costa no curso de mestrado do Programa de PósGraduação em Direito da UFRGS, durante o primeiro semestre de 2000. Agradecemos à professora todo o auxílio prestado - verdadeira conditio sine qua non deste nosso esforço - e ao professor Almiro do Couto e Silva a paciência e um par de indicaçôes bibliográficas valiosas.

"Jeder hat das Recht auf die freie Entfaltung seiner Persönlichkeit, soweit er nicht die Rechte anderer verletzt und nicht gegen die verfassungsmäßige Ordnung oder das Sittengesetz verstößt" (Todos têm o direito ao livre desenvolvimento da sua personalidade, desde que não violem os direitos de outrem e nâo atentem contra a ordem constitucional ou a lei moral). O substantivo alemão Entfaltung seria melhor traduzido, talvez, por "desdobramento"; optamos por "desenvolvimento", contudo, por já restar consagrado como termo da expressão "livre desenvolvimento da personalidade".

Revista da Faculdade de Direito da UFRGS, v. 19, Março/2001 
gerada a partir da recepção pela ciência do $\mathrm{Di}$ reito da noção ética de personalidade, experimentou um período de ocaso durante os anos da ruptura totalitária ${ }^{2}$ proporcionada pelo regime nacional-socialista, mas foi justamente retomada pela jurisprudência alemã do pós-guerra. No ordenamento jurídico brasileiro, inexiste um dispositivo paralelo ao art. 2, 1, da Lei Fundamental alemã. Conhecemos, no entanto, o princípio fundamental da dignidade da pessoa $h u-$ mana ${ }^{3}$, conforme previsto no art. 1.., III, da Constituição de 1988. A principal pretensão deste trabalho é demonstrar que o direito ao livre desenvolvimento da personalidade vigora também no Brasil, como princípio implícito que embasa, especificamente no âmbito do Direito privado, tanto a tutela da intimidade (aspecto negativo) quanto a autonomia privada (aspecto positivo) ${ }^{4}$.

Assim, começaremos por examinar como surgiu historicamente a noção de personalidade na doutrina européia, distinta em sua fonte do conceito jurídico de pessoa, que será igualmente tratado. Concentraremos a atenção nas idéias desenvolvidas na Alemanha, para não fugirmos ao tema proposto: o pensamento de Immanuel Kant, em tal análise, ocupa lugar essencial, e se as obras consultadas são de origem predominantemente alemã, as razões são óbvias.

Esse panorama histórico é causa do que será abordado na segunda parte, que versará, então, sobre a fértil atividade jurisdicional verificada na Alemanha a partir da promulgação da Lei Fundamental, com o decisivo impulso do BVerfG e de inúmeros doutrinadores

2 A expressão é de Hannah Arendt (apud: LAFER, A reconstrução dos direitos humanos. Um diálogo com o pensamento de Hannah Arendt, São Paulo, Companhia das Letras, 1999, passim). Voltaremos a esse ponto adiante (v. parte I, 2.2).

3 A dignidade da pessoa humana também encontra-se expressa como norma constitucional na Alemanha (art. 1, 1, da Lei Fundamental de 1949), antecedendo, como sua base, o artigo referente ao direito ao (art. 1, 1, da Lei Fundamental de 1949),
livre desenvolvimento da personalidade.

4 Até onde sabemos, o mérito da distinção de aspectos negativo e positivo da defesa da personalidade, como tarefa central do Direito privado, pertence a HESSE, Derecho constitucional y Derecho privado, trad. por Ignacio Gutiérrez-Gutiérrez, Madri, Civitas, 1995, p. 74 e ss.

Revista da Faculdade de Direito da UFRGS, v. 19, Março/2001 complementam a bibliografia utilizada. vezes de Corte Constitucional no nosso país; tuicão após a promulgação da CRFB; zeram com que merecesse - não sem motivo. TE NA ALEMANHA)

A. Pessoa e personalidade tedescos, especialmente no que se refere à apl cação dos direitos e garantias fundamentais no

Isso posto, passaremos enfim à análise do ordenamento constitucional e da jurispruencia brasileira, visando a afirmar a direito ao livre desenvolvimento da personalidade em nosso sistema jurídico. Nessa tarefa, serão consalusões a autores nacionais, que

Por último, alertamos que a pesquis jurisprudencial realizada, dentre os tribunais bra-

ao Supremo Tribunal Federal (STF), por fazer as da jurisprudência brasileira, desde sua instie inovadora que alguns de seus acórdãos fi-

- O PROCESSO DE RECEPÇÃO DA PERSONALIDADE (ESPECIALMEN-

Origens do conceito jurídico de pessoa A primeira noção que devemos ter presente é que o conceito jurídico de pessoa nem sempre representou o que hoje significa: seu sentido e alcance são condicionados historicamente pelo valor que lhe foi atribuído em diferentes épocas e locais.

Em Roma, ao contrário do que se poderia pensar, considerava-se persona qualquer ser humano - inclusive os escravos ${ }^{5}$. A diferente situação destes em relação aos homens livres baseava-se, em verdade, na atribuição de capacidade jurídica somente aos últimos ${ }^{6}$. Nada impedia que uma pessoa fosse juridicamente tratada como coisa ${ }^{7}$, idéia que hoje nos causa estranheza; de qualquer modo, eram sinônimos os conceitos de pessoa e de ser humano.
No decorrer dos séculos, contudo, verificamos uma dissolução dessa sinonímia. Se, por um lado, algumas culturas arcaicas ampliavam a condição de pessoa a objetos e animais ${ }^{8}$, concepção que perdurou durante a Idade Média ${ }^{9}$, de outra parte houve não raras ocasióes em que nem todos os seres humanos eram personificados. Nesse sentido, foram necessárias pelo menos duas grandes conquistas teóricas, a fim de superar o estágio anterior:

a) em primeiro lugar, a idéia de que "apenas os seres humanos são pessoas" ${ }^{10}$. Com fundamentos na teologia moderna, deve-se em grande parte à obra de Tomás de Aquino (1225-
${ }^{5}$ KASER, Direito privado romano, trad. por Samuel Rodrigues e Ferdinand Hämmerle, Lisboa, Fundação Calouste Gulbenkian, 1999, p. 99. No periodo pós-clássico, os romanos passaram a usar o termo persona preferencialmente para desionar as pessoas livres. Cf PONTES DE MIRANDA, Tratado de Direito privado, 2.? ed., Rio de Janeiro, Borsoi, 1954-66, t. I, \& 48, 3

- Quanto à graduação da capacidade jurídica, afirma KASER: "Enquanto hoje a capacidade jurídica é entendida de modo unitário, com base na liberdade e na igualdade de todos os homens perante a lej, os Romanos, $\dot{a}$ questão sobre quais os direitos que competem a cada indivíduo, respondem de forma diferente para cada grupo de pessoas. Distinguem-se três pontos de vista segundo os quais pode segraduada a situação jurídica do indivíduo: segundo a liberdade (ibertas), a cidadania (civitas) e a posição na família" (op. cit., pp. 99100).

"De fato, em Roma, "juridicamente os escravos são ao mesmo tempo res (objeto de direito) e personae" (KASER, op. cit, p. 107), caracterizando-se por serem considerados "incapazes de ser sujeito de direitos públicos e privados" (p. 106). No entanto, comopersona aliena iuris que era, o escravo romano podia ter um peculium cedido pelo dono, para sua administração autônoma, apesar de que a propriedade do pecúlio permanecia com o cedente (p. 108). A ênfase, em suma, localizava-se na noção de capacidade jurídica - e não no conceito de pessoa -, revelando um posicionamento ideologico que, em razão dos trabalhos da Pandectística conforme se verifca pela letura tanto do $\mathcal{S} 1 .-$ do BGB quanto do art. 2.- do Código Civil brasileiro (v. infra). A esse respeito, especificamente quanto à experiência alemā, v. HATTENHAUER, Conceptos fundamentales del Derecho civil. Introducción histórico-dogmática, trad. por Gonzalo Hernández, Barcelona, Ariel, 1987,
pp. 13-14.

$\therefore$ Alguns exemplos curiosos nos são fornecidos por PONTES DE MIRANDA, ao discorrer sobre o nexo necessário entre responsabilidade $e$ a condição de pessoa, como quando "em Tasos, no século $I V$, em ação intentada pelo filho da vítima, esmagada pela estátua do Atleta Teagenes, foi essa condenada e lançada ao mar" (op. cit, t. LIII, $\$$ 5.498, 2). E conclui o jurista brasileiro: "(...) o que objetivamente de tudo isso nos fica é a tentativa de submeter os animais e as coisas ao expediente adaptativo, que forra proficuo no homem e falhou nos demais seres" (idem). Em sentido semelhante, HATTENHAUER resume tal tendência do espírito humano: "Siempre que el hombre deposita su confianza en algo, surge esa técnica de la personificación de cosas e ideas" (op. cit., p. 14).

9 HATTENHAUER, op. cit, p. 15.

${ }^{10}$ Tratamos apenas das pessoas fisicas; não interessam ao presente estudo as pessoas jurídicas stricto sensu, fictícias, fingidas ou morais, conforme a nomenclatura preferida. 
74), bem como ao seu posterior desenvolvimento pelos jusnaturalistas espanhóis, no século XVI, mormente face às novas experiências proporcionadas pelo descobrimento do Novo Mundo ${ }^{11}$;

b) em segundo lugar, a constatação de que "todos os seres humanos são pessoas". Trata-se de noção igualmente aperfeiçoada à época do descobrimento da América, como resposta dos representantes do jusnaturalismo cristão à questão inarredável de reconhecer-se ou não os índios como pessoas ${ }^{12}$.

Somente assim, respirando-se já os ares humanistas do Renascimento, foi alcançado o conceito jurídico moderno de pessoa, em cujo suporte fático se encontra apenas a condição humana ${ }^{13}$. É realmente formidável o avanço representado por essa junção de idéias

jusnaturalistas, a consagrar o princípio da igualdade formal entre os homens, sendo recepcionada e celebrada pelos pensadores do Iluminismo; nas palavras de Hans Hattenhauer "a Humanidade se converteu, assim, numa autêntica comunidade de Direito de hierarquia superior" ${ }^{14}$

Não podemos esquecer, a essa altura, a lição de Johannes Althusius (1557-1638), quando registrou em seu Epitome Dicaeologiae Romanae que "persona est homo iuris communionen habens" (a pessoa é o homem como co-partici pante do Direito) ${ }^{15}$. Ou, numa tentativa de formulação lógica: (a) só há pessoa se houver ser humano, mas (b) só há ser humano se houver sociedade, de modo que (c) só há pessoa se houver ser humano e sociedade. Persiste aí uma inter-relação necessária ${ }^{16}$.

"Com efeito, como explica HATTENHAUER, "a la vista de las riquezas naturales de América, consideradas incomensurables, carecía de sentido seguir reconociendo a la Creación inanimada, vegetal o animal, la calidad de persona y, consecuentemente, el beneficio de la protección jurídica, por lo que la doctrina de los iusnaturalistas puso esta parte de la Creación a libre disposición de los conquistadores" (op. cit, p. 15).

12 Uma resposta negativa, i.e., que não reconhecesse a condição de pessoa aos índios, a princípio conflitaria com o disposto na Bíblia, ao identificar na razão inerente a todo ser humano o sopro divino (HATTENHAUER, op. cit., p. 15). LAFER menciona ainda as seguintes palavras de São Paulo (Epistola aos Gálatas, 3, 28): "não há judeu, nem grego, não há escravo nem livre, não há homem nem mulher, pois todos vós sois um só em Cristo Jesus" (op. cit., p. 119).

13 "La condición de humano era el único requisito necesario para alcanzar la prerrogativa de persona y no lo eran otras cualidades añadidas, como la fe verdadera, la recta conciencia, el adecuado linaje, el sexo, la posición o el origen privilegiados. Para ser persona no debía tenerse por impedimento que alguien fuera hereje, incrédulo, indio, judío, mujer o vagabundo" (HATTENHAUER, op. cit., p. 16); v. ainda PONTES DE MIRANDA, op. cit., t. VII, $\mathcal{S} 727,1$

${ }^{14}$ HATTENHAUER, op. cit., p. 16 (traduzimos).

${ }^{15}$ HATTENHAUER, op. cit., p. 17. A obra de Althusius é fundamental para o desenvolvimento da teoria jusnaturalista do contratualismo, durante os séculos XVII e XVIII, seja na acepção a ela dada por Thoma Hobbes (1588-1679), John Locke (1632-1704) ou Jean-Jacques Rousseau (1712-78) - v. BOBBIO, Direito e Estado no pensamento de Emanuel Kant, trad. de Alfredo Fait, 4. ${ }^{\mathrm{g}}$ ed., Brasilia, Universidade de Brasília 1997, p. 27; LAFER, op. cit., pp. 121-122.

${ }^{16}$ Numa passagem fascinante de seu livo, HATTENHAUER indica a representaçâo literária dessa idéia no Robinson Crusoe, de Daniel Defoe, que serviria como "una expresiva demostración de la veracidad de la teoría social del Derecho natural" (op. cit., p. 18): a personagem principal, até encontrar o nativo Sexta-feira, não seria pessoa na acepção jurídica do termo - mas sim, unicamente, um homem. O mencionado encontro, por sua vez, representa o "contrato" pelo qual nasce a sociedade civil e, ao mesmo tempo, o Direito e condição de pessoa.

Revista da Faculdade de Direito da LFRGS, v. 19, Março/2001
Logo, para podermos conceituar pessoa é mister que estejam indissociavelment compreenclidas tanto a dimensão individual quanto a dimensão social do ser humano ${ }^{17}$ - a sociedade é formada pela soma dos indivíduos que, por sua vez, dela de pendem para desenvolverem-se como pessoas. A supressão de qualquer uma dessas dimensões do ser humano conduz, inevitavelmente, à alguma espécie de totalitarismo.

Não foi à toa que Hannah Arendt considerou Jean-Jacques Rousseau (1712-78) "o primeiro teórico moderno da intimidade enquanto rebelião do indivíduo" ${ }^{18}$, pois a preocupação do filósofo genebrino centrou-

se, pelo menos em seus últimos escritos, justamente em emancipar a dimensão individual do ser humano do "conformismo nivelador da sociedade" 19 . O que veremo a partir do século XIX, em contrapartida, é a consagração excessiva do individualismo pelo pensamento liberal burguês, a atentar agora contra a dimensão social do ser humano ${ }^{20}$

Ao identificar o individualismo como uma das dimensões da tradição que ensejou tema dos direitos humanos, conforme lição de Arendt, escreveu Lafer tratar-se de "parte integrante da lógica da modernidade que concebe a liberdade como a faculdade

17 Lembramos aqui, a título de ilustração, a história narrada pelo personagem Jacobina no conto "O espelho", de MACHADO DE ASSIS, para justificar sua tese sobre a alma humana: "Cada criatura humana traz duas almas consigo: uma que olha de dentro para fora, outra que olha de fora para dentro (...); as duas completam o homem, que é, metafisicamente falando, uma laranja. Quem perde uma das metades, perde naturalmente metade da existência; e casos há, não raros, em que a perda da alma exterior implica a da existência inteira" (in: Obra completa, Rio de Janeiro, José Aguilar, 1959, vol. II, pp. 341-342).

18 LAFER, op. cit., p. 264

19 LAFER, op. cit., p. 266. Confessadamente inspirada no pensamento de Rousseau quanto à proteção da intimidade, Hannah Arendt propôs, em seu polêmico artigo "Reflections on Little Rock", a exclusividade como principio central da esfera privada - contraposta à iguald ade como principio central da esfera pública Oreconhecine to de um principio que tutele onight to be let lone, ratifca LAFER, é idispensac Oreconhecin cor assegurar ao indinduo a sua identide dine dos riscos de de instaurar-se uma situação-limite de totalitarismo moral, a que Arendt dá o nome de desolação. Éo que ocorreu durante a experiência nacional-socialista na Alemanha, vivenciada e combatida por Arendt, que desenvolveu sua doutrina justamente a partir da idéia dessaruptura (LAFER, op. cit., p. 117 e ss.).

${ }^{20}$ Ainda hoje essa exaltaçâo do individualismo desperta críticas na doutrina, como as feitas pelos representantes do chamado humanismo jurídico (e.g., EDELMAN, La personne en danger, Paris, Presses Universitaires de France, 1999, p. 503 e ss.). Em França, comentou esse posicionamento crítico OPPETTT: "Ia destruction de l'idée de nature, en provoquant une exaltation incontrôlée de l'individu et de ses droits subjectifs, aurait affranchi ces derniers de toute limite et instauré l'omnipotence absolue du sujet, qui ne rencontre d'autres limites que la réalisation même de ses désirs, notamment dans le monde de la technique et de l'économie" (Philosophie du Droit, Paris, Dalloz, 1999, p. 135). Logo após, contudo, OPPETIT advertiu quanto ao perigo contrário - i.e., uma aniquilaçâo da dimensão individual da pessoa mediante uma juridicização excessiva da Moral -, alertando que "il n'existe pas de morale officielle, droit et morale recouvrant des domaines distincts" (op. cit, p. 137). Em sum an entendemos que a relacão entre ambas as dimensôs apresenta caráter dialetico, razão pela qual um dos pólos sempre dependerá da manutenção do outro. En breve análise da dialética na experiência juridica, v. REALE, Ciência do Direito e dialética, in:Horizontes do Direito e da História, 3.? ed., São Paulo, Saraiva, 2000, pp. 343-348. 
de autodeterminação de todo ser humano"21. O ponto culminante dessa lógica pode ser identificado em Immanuel Kant (1724$1804)^{22}$, cujo criticismo, ao mesmo tempo em que informou as bases para uma nova classificação da razão, representou o fecho de vários séculos de pensamento filosófico quanto à questão moral da liberdade.

2. A personalidade como categoria ética

No momento de transição histórica pre-

parado pelo Iluminismo e representado pela $\mathrm{Re}$ volução Francesa, portanto, Kant inaugurava a deontologia moderna da pessoa. No núcleo dessa nova concepção, cujos antecedentes acima pretendemos expor, encontra-se essencialmente vinculada ao valor liberdade a noção de personalidade, como veremos.

Em 1785, Kant publicou uma Fundamentação da Metafisica dos costumes, estudo preparatório à sua Crítica da razão prática (1788)

${ }^{21}$ LAFER, op. cit., p. 120. Com efeito, encontramos as origens epistemológicas do individualismo tanto no voluntarismo de Duns Scottus (1266-1308), que primeiro consagtou a preeminência do intelecto, quanto no nominalismo do teólogo inglês Guilherme de Occam (1300-50), que afirmou o primado gnoseolóoico da subjetividade sobre a coletividade. No campo religioso, as rá́zes estão na Reforma que, por assim dizer,

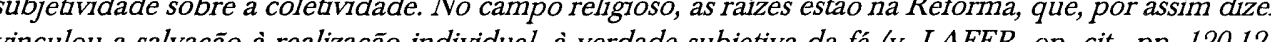
vinculou a sal WIEACKER, História do Direito privado moderno, 2. ed., trad. por A. M. Botelho Hespanha, Lisbo Fundação Calouste Gulbenkian, 1993, p. 285, nota 19; HESPANHA, Panorama histórico da cultura jurídica
europeia, 2. ${ }^{\circledR}$ ed., Europa-América, 1998, pp. 62-65).

A partir desse panorama, torna-se possivel a Hugo Grócio (1583-1645) empreender a laicização do Direito natural, transferindo o seu fundamento para arazão - nada mais de acordo com a incipiente ciência moderna cujas bases seriam sistematizadas em breve por René Descartes (1596-1650), já que a obra-prima de Grócio, De iure belli ac pacis libri tres (1623), foi publicada poucos anos antes dos escritos teóricos fundamentais de De iure belli ac pacis libri tes (1623), for publicada poucos anos antes dos escritos teoricos fundamentais de (1628), o famoso Discurso do método (1637) e seus Princípios da Filosofia (1644). Não obstante, há divergência na doutrina no que se refere a ser ou não Grócio o fundador de um sistema jus-racionalista. WIEACKER, por exemplo, apontando a íntima ligação do jurista holandês com a tradição medieval da teologia moral da escolástica tardia, sustenta que descabe a consagração de Grócio como precursor do Iluminismo: "o impacto de Grócio é antes fundado (...) no seu eficaz papel de mediador entre a tradição da teologia moral e o futuro jus-racionalismo profano. Ao contrário do que aconteceu com a tradição da Igreja Católica, Grócio pôde ser directamente adoptado pelo iluminismo deísta e tornar-se, assim, influente, no pensamento profano" (op. cit., pp. 337-338).

De qualquer modo, a emancipação de uma ética social autônoma é continuada e desenvolvida por Samuel Pufendorf (1632-94), jurista de formação luterana que expulsa a revelação do domínio da razão natural e a encaminha para o domínio da fé (WIEACKER, op. cit., p. 347). Já contando com a influência do mecanicismo de Galileu e do racionalismo de Descartes, ele deixou expresso que a socialitas (dimensão social do ser humano) e a imbecillitas (dependência do ser humano em relação aos seus semelhantes) não advêm de meros impulsos fisiologicos; são categorias que representam, isto sim, axiomas éticos (op. cit., p. 350). WIEACKER ressalta a formidável influência que a obra de Pufendorf exerceu sobre o Iluminismo dos Estados autoritários da Europa central e, posteriormente, sobre as primeiras codificaçôes modernas, ao estabelecer os pressupostos metodológicos para uma ética social autônoma e sistemática, à semelhança do que Descartes realizara em relação ao pensamento científico (op. cit., p. 353); assim, inclusive, "a 'parte geral' de muitos dos novos códigos seria dificilmente pensável sem o trabalho prévio de Pufendorf" (op. cit, p. 350). Por outro lado, HESPANHA destaca ainda a importancia da filosofa utilitarista de Jeremy Benth mento codificatorio moderno (op. cit., pp. 162-164).

${ }^{22}$ No aspecto ora estudado, a obra kantiana sofreu confessada influência de Rousseau e, em grau ainda mais alto, do filósofo escocês David Hume (1711-76), conforme indica IMAZ (Prólogo, in: KANT, Filosofia de la Historia, trad. de Eugenio Imaz, 1. ${ }^{a}$ ed., México, Fondo de Cultura Económica, 1941, p. 2).

Revista da Faculdade de Direito da UFRGS, v. 19, Março/2001 com a qual ambicionou formular uma filosofia moral pura, ou seja, despida de qualquer fator empírico - a essa posição quanto à origem do conhecimento filosófico, inaugurada pelo pensador alemão em sua Crítica da razão pura (1781), dá-se o nome de apriorismo ${ }^{23}$. Cabe ressalvarmos, contudo, que a priori, aqui, não significa "inato" nem "temporalmente anterior", mas tão-somente "o que independe da experiência individual" ${ }^{24}$.

Podemos notar, portanto, que, embora compreendido dentro da tradição iluminista que (re)coloca o ser humano no centro das preocupações filosóficas, seria um equívoco acusar Kant como precursor teórico do individualismo burguês que veio a moldar o século XIX. Tal não foi o seu intento; pelo contrário, encerrado em sua cidade natal de Königsberg, pregou o amor incondicional à lei moral e preocupou-se em estabelecer uma Metafísica dos costumes justa-

${ }^{23}$ SALGADO MARTINS, Preparação à Filosofia, 3. ${ }^{a}$ ed., Porto Alegte, Globo, 1978, pp. 50-54.

24 SALGADO MARTINS, op. cit., p. 52.

${ }^{25}$ KANT, Fundamentaçâo da Metafísica dos costumes, trad. por Paulo Quintela, in:Os pensadores: Kant, 1. ${ }^{\text {t }}$ ed., São Paulo, Abril Cultural, 1974, p. 199. A busca de uma razão pura para a Ética, contudo, parece ter experimentado as mesmas dificuldades a que ficou sujeita, no campo jurídico e já no século XX, mutatis mutandi, a teoria pura do Direito, conforme formulada por Hans Kelsen: ambas as teses possuíam objetivos nobres, mas conduziram a resultados práticos de eficácia duvidosa. O próprio $K A N T$, aliás, reconhece os problemas inerentes à aplicação de uma razão pura prática: "O homem, com efeito, afetado por tantas incliną̧ões, é na verdade capaz de conceber a idéia de uma razão pura prática, mas não é tão facilmente dotado da força necessária para tornar eficaz in concreto no eu comportamento" (Fundamentarão cit, 199). Nesse sentido, em última análise, a doutrina kantiana apoia-se toda na confiança em relação à moralidade humana, como notamos na sua famosa regra: "(..) devo proceder sempre de maneira que eu possa querer também que a minha máxima se torne uma lei universal" (Fundamentação cit., p. 209).

${ }^{26}$ KANT, Fundamentação cit., p. 205.

${ }^{27}$ Não adentraremos esse ponto específico, sem dúvida muito rico, por fugir ao tema deste trabalho. Basta fazer menção às discussões em tomo do combate ao "dogma da vontade", com o estabelecimento de limites à autonomia privada, bem como ao reconhecimento de uma funçāo social aos institutos de Direito privado, citando-se aí a obra pioneira de GIERKE, já em fins do século XIX (La función social del Derecho privado,
trad. por José M. Navarro de Palencia, Madri, Sociedad Editorial Española, 1904); v. ainda HATTENHAUER, trad. porJosé $M$. Navi
op. cit, pp. $73-76$.

${ }^{28}$ Especificamente sobre o posicionamento de Kant em relação aos eventos da Revolução Francesa, v. o ensaio de BOBBIO, Kant e a Revoluçẫo Francesa, in: A era dos direitos, trad. por Carlos Nelson Coutinho, Rio de Janeiro, Campus, 1992, pp. 131-141.

${ }^{20}$ LAFER, op. cit., p. 121. mente "porque os próprios costumes ficam sua

É inegável, de qualquer maneira, que a no uso da razão humana com a concomitante acabou por dar espaço a um voluntarismo que até hoje é combatido pelos juristas ${ }^{27}$. Ao mesmo iluminista, consistiu num passo fundamental para a consagração dos direitos humanos, já a

Nesse sentido, escreve Lafer que "este de secularização (do Direito natural) com o sapere aude kantiano, ou seja, com a liberdade do uso autônomo da própria Que

Revista da Faculdade de Direito da UFRGS, v. 19, Março/200 
é a ilustração? (1784), publicado pouco antes da Revolução Francesa, Kant celebrava o uso autônomo da razão humana, como ato de liberdade moral, ao mesmo tempo em que tal atitude representaria a saída do estado de "incapacidade culpável" dentro do qual se encontraria o gênero humano ${ }^{30}$

Entendia o filósofo alemão que a renúncia pura e simples a esse dever moral, ainda que fosse em nome da própria pessoa, significaria, em suas palavras, tanto como violar e pisotear os sagrados direitos do homem ${ }^{31}$. É sensivel, portanto, em Kant, a vinculação da personali-

dade ao dever ético de utilizar autônoma e racionalmente a liberdade, em atinência com a natureza humana ${ }^{32}$

"Algo mais que uma máquina", com efeito, é o ser humano para Kant ${ }^{33}$, tornando-se imprescindivel o reconhecimento de sua dimensão ética, de sua condição de homo noumenon ${ }^{34}$ - vale dizermos, de sua personalidade $^{35}$. Ou seja: como pessoa que é, o ser humano tem direitos e deveres em suas relações com os demais seres humanos, como pessoas que são, a consagrar o respeito recíproco como princípio fundamental do Direito ${ }^{36} ;$ em outras

Sintetizando o espírito iluminista, bradava KANT: "Para esta ilustración no se requiere más que una cosa libertad; y la más inocente entre todas las que llevan ese nombre, a saber: libertad de haceruso público de su razón întegramente" ('Qué es la ilustración?', in:Filosofia cit., p. 28).

${ }^{31} K A N T$, ¿Qué es cit., p. 33.

${ }^{32}$ Essa idéia foi reiterada por KANT em vários escritos. Assim, e.g., na conclusão de sua Crítica da razão prática (trad. por Artur Morão, Lisboa, Ediçōes 70, 1997), onde expressa sua admiração e veneração por duas coisas, acima de tudo: "o céu estrelado sobre mim e a lei moral em mim"; esta lei moral interna, para KANT, justamente a personalidade, que "eleva infinitamente o meu valor como inteligência" e "me descobre uma vida independente da animalidade e mesmo de todo o mundo sensível" (pp. 183-184).

${ }^{33}$ Destarte escreveu o filósofo: "(...) cuando la Naturaleza ha logrado desarrollar, bajo esta dura cáscara, esa semilla que cuida con máxima ternura, a saber, la inclinación y oficio dellibre pensar del hombre, el hech repercute poco a poco en el sentir del pueblo (con lo cual éste se va haciendo cada vez más capaz de la libertad de obrar) y hasta en los principios del Gobiemo, que encuentra ya compatible dar al hombre, quees algo má que una máquina, un trato digno de él" (KANT, ¿Qué es cit., p. 37 - grifamos).

3t Nesse sentido, comentando a obra kantiana, acrescenta IMAZ: "(..) el homo noumenon empieza a ser la humanidad -Menschheit - en el hombre y termina siendo la humanidad de los hombres: la especie moral. La especie moral es la que tiene un destino que cumplir: un bien supremo que alcanzar" (op. cit, p. 16). respeito da necessidade de utilizarse a Humanidade na pessoa do homem sempre como fom - cunca como meio - comentou WELZ meio -, comentou WELZEL que tal formula, ti picamente idealista, significaria "Uilizar la persona en su existencia empinica, solo en tanto que su hacer opadecer es en síla realizacion o venificacion de la person moral" Introducción a la Filosofia del Derecho. Derecho natural y justicia material, trad. por Felipe González Vicén, Madri, Aguilar, 1971, pp. 180-181).

${ }^{35}$ Podemos perceber, apesar disso, que a noção kantiana de personalidade ainda guarda traços típicos do pensamento iluminista, i.e., assemelha-se a um título honorifico, a um predicado dos grandes homens, daqueles que agiam conforme a lei moral interna. Conforme HATTENHAUER, à diferença do conceito de pessoa, que desde Roma mantivera a sua natureza jurídica, a personalidade era para Kant "una cualidad ética una capacitación para la libertad en la que debería desenvolverse el hombre" (op. cit p. 21). A consagracaso

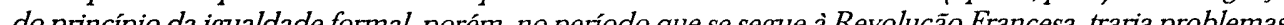
do principio da igualdade formal porém, no período que se segue à Revolusẫo Francesa, traria problemas a essa concep̧̧ão

${ }^{3}$ LARENZ, Derecho justo. Fundamentos de Ética jurídica, trad. por Luis Díez-Picazo, Madri, Civitas, 1993, pp. 56-57. Seguindo a lição de Kant, ao menos nesse particular, declararia mais tarde Friedrich Hegel (1770 1831): "El mandamiento jurídico es: sé una persona y respeta a los demás como personas" Rechtsphilosophie, \$ 36, apud: LARENZ, Derecho cit., p. 57).

Revista da Faculdade de Direito da UFRGS, v. 19, Março/2001 palavras, trata-se de reconhecer a dignidade pessoal do outro em quaisquer circunstâncias.

A personalidade, assim, desprende-se totalmente de sua raiz religiosa e, com arrimo numa reforçada base ética de liberdade, encontra pleno reconhecimento na deontologia kantiana.

B. O problema da tutela jurídica da personalidade

\section{1 - Direito geral da personalidade}

Se o reconhecimento da personalidade como categoria ética foi atingido em sua plenitude na obra de Kant, o problema da sua tutela ticos no desenrolar do século XIX.

De fato, verificou-se uma redução doutrinária da noção de personalidade, notadamente pela Pandectística alemã, à mera capacidade ju rídica ${ }^{37}$, tomando-se o conceito de pessoa em seu aspecto estritamente formal - ou seja, como simples "material para a construção de relaçōes jurídicas" ${ }^{38}$. Nesse sentido, p.ex., Friedrich von Savigny (1779-1861) nem trata mais da pessoa, no singular - mas das pessoas, no plural, pois são necessárias no mínimo duas para constituir uma relação jurídica. Em suma, como explica Hattenhauer, "a ordem jurídica situava-se po cima do individual, como algo objetivamente preestabelecido, a que a pessoa tinha de se acomodar" ${ }^{39}$. jurídica, porém, conheceu graves problemas prá-

Tal perspectiva, no entanto, começou a ser questionada na Alemanha ainda no século XIX. Em 1866, o civilista alemão Georg Carl Neuner (1815-1882) publicou o livro Wesen und Arten der Privatrechts-verhältnisse, que - apesar de manter-se preso à doutrina savigniana do primado, por assim dizer, da relação jurídica sobre a pessoa - fez primeiro menção a um "Direito da personalidade" ${ }^{40}$. Seu caráter pioneiro é ressaltado, ainda, pela vinculação da personalidade à afirmação do que chama de Direito fundamental (e isso tudo, vale lembrarmos, no âmbito do Direito privado, que adquiria assim um pathos constitucionalista) $)^{41}$.

Os conceitos de pessoa e personalidade, todavia, continuaram obscuros pelo menos até o início do século $\mathrm{XX}$, não obstante o desenvolvimento teórico que vinha experimentando a idéia de um Direito da personalidade. Em 1895, Otto von Gierke (1841-1921) escrevera seu Deutsches Privatrecht, obra na qual restou enunciado, pela primeira vez, um "Direito geral da personalidade", nos seguintes termos:

"Chamamos Direito da personalidade aquele que garante a seu sujeito o domínio sobre um setor da própria esfera de personalidade. (...) Os direitos da personalidade são diferentes, como direitos privados especiais, do Direito geral da personalidade, que consiste numa reivindicação geral, garantida pelo ordenamento jurídico, de contar como pessoa. O Direito da personalidade é um direito subjetivo que deve ser respeitado por todos." ${ }^{42}$

${ }^{37}$ Quanto à equiparação entre personalidade e capacidade jurídica, formalmente consagrada durante o processo de codificação civil no século XLX, marcadamente na Alemanha $\left(\mathcal{S} 1 .{ }^{\circ}\right.$ do BGB), mas com reflexos também no ordenamento brasileiro (art. $2^{\circ}$ do Código Civil), v. nota 7 (supra).

${ }^{38}$ HATTENHAUER, op. cit., p. 19 .

${ }^{39}$ HATTENHAUER, op. cit., p. 20.

${ }^{4}$ Cf. CAMPOS Liçōes de direitos da personalidade, 2.ㄹed., Coimbra, Universidade de Coimbra, 1995, p.

49), ao afirmar que, já na primeira metade do século XIX, Puchta havia reconhecido direitos da personalidade.

"I HATTENHAUER, op. cit., p. 22; v. infra, parte II, 1.1.

42 Deutsches Privatrecht, I, pp. 702 e ss. (apud: HATTENHAUER, op. cit., p. 23 - traduzimos e grifamos). 
Num discurso lido em 1899 perante a Associação de Jurisconsultos de Viena, sob título $A$ função social do Direito privado - sem dúvida avançado em relação ao seu tempo Gierke voltou a reforçar a importância da per sonalidade no Direito privado. Nesse sentido após discorrer sobre a urgência de limitar-se liberdade contratual, tornada absoluta pela ideologia liberal oitocentista, bem como tomar-se como guias os interesses socialmente mais relevantes, concluiu o jurista alemão que, ao invés de priorizar noções outras, deve o Direito priva do trazer sempre em seu centro o conceito de personalidade ${ }^{43}$

Não obstante, questionava-se a necess dade de uma tal teoria, uma vez que o arsena teórico dos aplicadores do Direito, à época, parecia suficiente, e um Direito geral da personalidade só poderia apresentar um valor de re serva, para garantir eventualmente novas formas de proteção jurídica da pessoa; assim ocorreu, e.g., no que se refere à propriedade intelectu$\mathrm{al}^{44}$. Entretanto, ainda em 1905, ano em que Edouard Hölder (1847-191 b) publicou sua obr Natürliche und juristische Personen, a imprecisão prevalecia.

E sabido que, no processo de elabor ção do Código Civil alemão (Bürgerliches Gesetzbuch-BGB), apesar das fundamentadas

GIERKE, op. cit., p. 44

* HATTENHAUER, op. cit, p. 23

${ }_{45}$ GIERKE, op. cit, passim. Condenando o espínto excessivamente ligado ao liberalismo burguês do século $X L X$, bem como a preferência pela cópia de antigas concepçóes romanas, em detrimento da recepção de institutos e regras historicamente desenvolvidos pelo Direito germânico, GIERKE concentra sua insatisfação quanto à codificação civil alemã - à época, ainda em tramitação legislativa - na seguinte passagem: " $E J$ Proyecto alemán exagera el principio de la libertad contractual en el derecho de obligaciones; en tanto que lo deprime violentamente, en el derecho sobre las cosas" (op. cit., p. 40, nota 1).

${ }^{46} A$ isso já fizemos referência nas notas 7 e 37 (V. supra).

47 HATTENHAUER, op. cit., p. 24

*s WIEACKER considera o ZGB, graças à obra de Eugen Huber, "o fruto legislativo mais amadurecido da ciência jurídica de língua alemẫ do séc. XIX" (op. cit,. pp. 564-569).

Revista da Faculdade de Direito da UFRGS, v. 19, Março/2001

críticas de Gierke $^{45}$, se adotou a doutrina jurídiobra teórica de Savigny em relação ao negócio jurídico. Assim sendo, em 1896, predominou a expressão "capacidade jurídica" no $\S 1 . .^{\circ}$ do BGB, sobrepondo-se a uma eventual menção a personalidade - o que podemos verificar igualmente, em 1916, no caso do Brasil (art. 2.. do Código Civil $)^{46}$

Destarte, mesmo que algumas críticas apresentadas por Gierke tenham sido levada em consideração na fase final do processo de elaboração do BGB, sua tese quanto a um Dimuseu das idéias porque o Código Civil suíco (Zivilgesetzbuch - ZGB) veio recebê-la, em enfoque substancialment seu elaborador, Eugen Huber (1849-1923), er

\section{A ruptura totalitária}

Após a derrota na Primeira Grande assinatura do Tratado de Versalhes, em condições extremamente desfavoráveis, a Alemanha viu ascender, em plena República de Weimar, o regime nacional-socialista. germânico, Adolf Hitler (1889-1945), assumiu direção do ainda inexpressivo Partido Nacional-Socialista dos Trabalhadores Alemães, fundado em uma cervejaria de Munique. De 192 a 1929, impulsionados por uma certa recuperação econômico-financeira no país, os nazista foram ganhando vulto político; em fevereiro de 1933, após incendiarem o parlamento (Reichstag) e culparem o movimento comunis ta, implantaram enfim uma ditadura na Alemanha. Ao Führer conferiram poderes de exceção, supraconstitucionais: supressão de todos os partidos políticos (exceto o Partido Nazista, po óbvio), dissolução dos sindicatos, cassação do direito de greve, fechamento dos jornais de oposição, estabelecimento da censura à imprensa implantação de polícia política, perseguição de judeus e outros grupos humanos considerados inferiores, etc ${ }^{49}$

Devemos ressaltar que Hitler não subiu sozinho ao poder: acompanhou-o todo um a

49 Devido a esse quadro que passou a existir na Alemanha, HESSE dedica ao regime "constitucional" do período nacional-socialista apenas um parágrafo de seuDerecho cit,, afirmando que, então, "no cabría hablar de una Constitución que vinculara también a los detentadores del poder, el Estado nada tenía que ver con un Estado Constitucional" (p. 53).

so LA TORRE, La "lotta contro il diritto soggettivo". Karl Larenz e la dottrina giuridica nazionalsocialista, Milão, Giuffrè, 1988, p. 1, nota 1. Nos casos de Larenz e Schmitt, p.ex., não teria havido mera adesão ao regime nacional-socialista, mas "convinta partecipazione a quel movimento politico (il cui successo i due
suddetti autori contribuirono a preparare per quanto era ad essi possibile con i loro scritti) ed alla conseguente Deutsche Rechtserneuerung" (pp. 1-2).

${ }^{51}$ LA TORRE, op. cit, pp. 34. Vale fazermos menção ao texto da circular que, em 1945, logo após o fim da Guerra, RADBRUCH fez distribuir aos estudantes da Universidade de Heidelberg, no qual apontava os males de uma e de outra concepsão do Direito, porquanto ambas negam principios jurídicos fundamentais "mais fortes do que todo e qualquer preceito juŕdico positivo" - ic os direitos naturas ou mentais, "mais forte do que todo e qu Fluer precelto juifdco pos nBRUCH, racionais da pessoa (Cinco numus de Firoso trad. por L. Cabral de Moncada, 6. ${ }^{a}$ ed., Coimbra, Arménio Amado, 1997, p. 417).

${ }_{52}$ Para KELSEN, o conceito de "pessoa" é meramente normativo, expressando apenas um "suporte" de deveres jurídicos e direitos subjetivos, sem qualquer substrato ético (Teoria pura do Direito, trad. por João Baptista Machado, 4. ${ }^{a}$ ed., São Paulo, Martins Fontes, 1995, pp. 188-194). Essa posicão é coerente com a separac a pregava (idem, pp. 7278), for un pregava (idem, pp. 7278), e for mantuda en obras posteriores à derrocada do regine nacionalsocialista na Alemanha (Teoria geral do Direito e do Estado, trad. por Luís Carlos Borges, 3. ${ }^{a}$ ed., São Paulo, Martins Fontes, 1998, p. 135-139). 
do a interpenetração entre as esferas jurídica e moral ${ }^{53}$.

Ambas correntes doutrinárias negavam o direito subjetivo, em troca de um espírito objetivo, a consagrar a figura do dever jurídico ${ }^{54}$. Todavia, suas diferenças de fundo eram marcantes ${ }^{55}$, e, do embate entre as duas posições, restou enfim vitorioso, com a ascensão do nacional-socialismo na Alemanha, o organicismo de Larenz. Como característica fundamental, esta doutrina reconhecia na sociedade (Volksgemeinschaft, devidamente compreendida como "a sociedade nazista") a única realidade; o indivíduo era considerado mero apêndice, como se privado de vida própria. Em sín- tese, nas palavras de La Torre, "o ordenamento coincide com a Volksgemeinschaft, e esta com o arbítrio do Führer" ${ }^{56}$.

Em vez dos direitos da personalidade, como teria apreciado Gierke, afirmava-se como fundamento da ordem jurídica (em geral, mas também no campo específico do Direito privado) o Führerprinzip, conforme explicitado por Schmitt ${ }^{57}$ - ou seja, a vontade geral de Larenz era, em última análise, a vontade do Führer. Com efeito, a promulgação da Lei do Cidadão do Reich (Reichsbürgergesetz-RBG), a 15 de setembro de 1935, extirpa o conceito de pessoa do ordenamento jurídico alemão e adota em seu lugar a noção de Reichsbürger (i.e., cida-

53 No entanto, LA TORRE procura demonstrar que, na época do nacional-socialismo, a posição supostamente ética de Larenz, em relação ao direito positivo, seria na realidade um amoralismo (op. cit., p. 4, nota 7).

${ }^{54}$ É oportuno apontarmos que a consciência (de parte) dos dirigentes nacionais-socialistas estava tranqüila justamente por alegarem que apenas cumpriam o seu dever, como bons cidadãos. Nesse sentido, lembramos o tardio julgamento de Adolf Eichmann, um dos arquitetos da chamada "soluçāo final" (i.e., o extermínio em

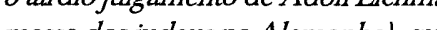
massa dosjudeur a Alevado a Cada da Justiça de Jerusalêm. ARENDT relata-nos que, durante seu interrogatorio, Eichmann invocou precisamente Kant e a noção de imperativo categórico: "O que eu quis dizer com minha menção a Kant foi que o princípio de minha vontade deve ser sempre tal que possa se transformar no princípio de leis gerais"; o réu afirmou ainda que lera a Crítica da razão pura e que, durante o período de crime legalizado pelo Estado nazista, se consolava com a idéia de que não era mais "senhor de seus próprios atos". ARENDT analisa os argumentos expostos e anota que a distorcão feita por Eichmann no teor do imperativo categórico kantiano respeitava a máxima cunhada por Hans Frank (Die Technik des Staates, 1942, pp. 15-16): "Aja de tal modo dizer onda desse tipo; ao contraic dizer nada desse upo, ao contrário, para ele todo homem é un legislador no momento em que começa a agi. usando essa 'razão prática' o homem encontra os princípios que poderiam e deveriam ser os princípios da les. Mas é verdade que a distorção inconsciente de Eichmann está de acordo com aquilo que ele próprio chamou de versão de Kant 'para uso doméstico do homem comum'. No uso doméstico, tudo o que resta do espírito de Kant é a exigência de que o homem faça mais que obedecer à lei, que vá além do mero chamado da obediência e identifique sua própria vontade com o princípio que está por trás da lei - a fonte de onde brotou a lei. Na filosofia de Kant, essa fonte é a razão prática; no uso doméstico que Eichmann faz dele, seria a vontade doFührer" (ARENDT, Eichmann em Jerusalém. Um relato sobre a banalidade do mal, trad. por José Rubens Siqueira, São Paulo, Companhia das Letras, 1999, pp. 153-154).

${ }^{55}$ LA TORRE arrola algumas críticas cunhadas por Larenz e seu mestre, Julius Binder, contra a obra kelseniana - não poucas, vale notarmos, de natureza inclusive pessoal (op. cit., p. 2, nota 2).

${ }^{56}$ LA TORRE, op. cit, p. 7 (traduzimos). Nesse sentido, o autor italiano aponta contradiçôes teóricas internas da doutrina nacional-socialista e cita, em especial, a obra Deutsche Rechtserneuerung und Rechtsphilosophie, escrita por Larenz em 1934 - mesmo ano em que foi publicada, em Viena, a primeira edição da Reine Rechtslehre de Kelsen.

${ }^{37}$ LA TORRE, op. cit, p. 22

Revista da Faculdade de Direito da UFRGS, v. 19, Març/2001

dão do Reich), nos termos do $§ 2 .{ }^{\circ}$ da referida lei:

"É cidadão do Reich unicamente o nacional de sangue alemão ou afim, que demonstre com seu comportamento que deseja e é apto a servir com lealdade ao povo e ao Reich alemães." ${ }^{8}$

Sem contar ter sido a prática ainda mais impiedosa que o teor do RBG, predominou durante o regime nacional-socialista um verdadeiro sistema de capacidades jurídicas escalonadas, que reconhecia certas pessoas como Untermenschen (i.e., infra-homens) ${ }^{59}$. Perdia-se, assim, o conceito jusnaturalista de pessoa e seus direitos; assumia primeiro plano a figura do camarada (Volksgenosse) e seus deveres $^{60}$.

Essa experiência representou, para Arendt, a ruptura totalitária, que ocasionou 0 ocaso dos direitos humanos mediante um processo de banalização e desolação ao qual se referiu, certa vez, como reductio ad Hitlerum ${ }^{61}$.

Com o final da Segunda Grande Guersuperação da doutrina jurídica nacional-socialista ensejou um juízo reflexivo que, de certo modo, até hoje se manifesta ${ }^{62}$. Mesmo juristas que haviam apoiado o regime totalitário enterraram suas antigas teses e passaram a pregar uma ra, em 1945, e nova derrota da Alemanha, a

\section{${ }^{58}$ Apud: HATTENHAUER, op. cit, p. 24 (traduzimos)}

${ }^{59}$ HATTENHAUER, op. cit., p. 25. Em consonância com o disposto no $\$ 2 .{ }^{\circ}$ do RBG, mesmo os camaradas alemães podiam perder sua condição de cidadãos do Reich e, com ela, sua dignidade quando não atendessem às expectativas do povo alemão (leia-se: do Führer). Nesse sentido, durante a Segunda Grande Guerra, horrorizaram até juristas simpatizantes do nacional-socialismo as sessóes de julgamento do Tribunal do Povo Alemão presididas pelo juiz Ronald Freisler. Em 1944, p.ex., ao interrogar militares alemães acusados de atentar à vida de um comandante do exército, Freisler exclamou aos berros que os réus não passavam de "velhacos sórdidos" impossibilita dos de sofrer, pois eram apenas "miseráveis". Tentava reprimir, assim, qualquer traço de dignidade que os acusados ainda possuiam, proferind ("burrice é algo do intelecto, porcaria é algo do caráter") que em verdade consistiam num comando de obediência irrestrita à vontade do Führer (ou seja, ao Führerprinzi p) - seria realmente absurdo, em tais circunstâncias, falarmos em direitos da personalidade. A respeito da justiça nacional-socialista, com cenas de alguns interrogatórios presididos pelo juiz Freisler, v. o interessante documentárioHitlers Helfer: Freisler der Hinrichter, vídeo legendado, 60 min., Alemanha, ZDF, 1998.

( Quanto à substituição do conceito de pessoa pelo de camarada, escreveu Larenz: "Decisivo para a posição jurídica do individuo não é mais basicamente sua condição de ser pessoa, senão sua condição concreta de membro da comunidade"; e ainda: "Camarada, em sentido jurídico, é apenas quem é camarada do povo: camarada do povo é apenas quem possui sangue alemão" Rechtsperson und subjektives Recht. Zur Wandlung der Rechtsgrundbegriffe, apud: $C U N H A$, Dignidade da pessoa humana: conceito fundamental de Direito civil, inédito, 1999, p. 27). O mesmo LARENZ, contudo, após a Segunda Grande Guerra, passará a enfatizar o conceito de pessoa em várias obras - e.g., no seguinte trecho: "(...) la condición de persona es la cualidad que distingue al hombre sobre todos los demás seres vivientes" "Derecho civil: Parte general, trad. por Miguel

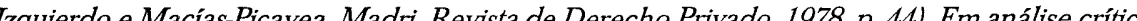
zquierdo e Mach Picavea Madi Revist de Derecho PHa concepcão totalitária do Direito, com arrimo na doutrina de Arendt e Lafer, além de interessante transcrição de
algumas passagens do Mein Kampf, de Adolf Hitler, v. CUNHA, op. cit., p. 27, nota 82 .

${ }^{61}$ LAFER, op. cit., p. 88.

${ }^{62}$ Especificamente quanto à (re)afirmação da liberdade humana, a partir da ruptura totalitária, no pensamento arendtiano, v. LAFER, op. cit., p. 299 e ss. 
Nascia uma nova ordem.

II - A APLICAÇÃO DO DIREITO AO LIVRE DESENVOLVIMENTO DA PERSONALIDADE NO DIREITO PRIVADO ALEMÃO E BRASILEIRO

A. A incidência da Constituição sobre o Direito privado

1. Direitos fundamentais e Direito privado

Se tem razão Ekkehart Stein ao afirmar que "todo o direito fundamental tem a sua raiz histórica numa prévia falta de liberdade contra a qual se dirige" ${ }^{64}$, a experiência constitucional da Alemanha após a Segunda Grande Guerra é, então, sem dúvida alguma, paradigmática. Daí a validade da seguinte idéia, apontada po Nuno Rogeiro justamente ao examinar o sistema alemão de direitos fundamentais: perspectiva axiológica e humanista do Direito, baseada na dignidade da pessoa ${ }^{63}$.

"Em certo sentido, afirmar um direito é re vogar, se o termo pudesse ser usado, um não-direito, assim como legiferar no sentido da liberdade é proscrever uma proibição."65

Em 23 de maio de 1949, na cidade de Bonn, é aprovada a Lei Fundamental. Em vigorosa oposição ao totalitarismo nacional-socialista do passado, concede especial relevo aos direitos fundamentais, compre endidos como direitos imanentes a todo e qualquer ser humano ${ }^{66}$; isso podemos comprovar mesmo pelas condições topográficas das respectivas normas, que encabeçam a Lei Fundamental alemã (arts. 1 a 19).

Outro fato de importância ímpar para a superação jurídica da ruptura totalitária na Alemanha, ao nosso ver, é a implantação de uma Corte Constitucional, em 12 de março de 1951. O BVerfG, de fato, previsto no art. 92 e ss. da Lei Fundamental, impõe-se como uma instituição-chave do novo sistema constitucional germânico, nos moldes de uma jurisdição constitucional efetiva, conforme imaginada por Kelsen $^{67}$.

${ }^{63}$ Em exame quase sarcástico desse processo de "regeneração" dos doutrinadores nazistas, v. HATTENHAUER, op. cit., p. 26. De fato, e.g., já em 1951 WELZEL editava seu Naturrecht und materiale Gerechtigkeit (utilizamos a tradução espanhola, op. cit.), no qual, procurando justamente investigar uma ética jurídica material, admitia, com palavras que se aproximam à doutrina kantiana, que "cuanto más intensamente intenta (...) el Derecho imponer por medio de la sanción una cierta concepción del mundo, tanto más intensamente entrará también en conflicto con la conciencia del individuo" (op. cit., p. 266). De modo similar, mais recentemente, LARENZ publicou um livro entitulado Richtiges Recht. Grundzüge einer Rechtsethik (citamos aqui também a tradução espanhola, Derecho cit.), o que outrora seria impensável. Não Rechtsethik (citamos aqui também a tradução espanh
vamos, contudo, empreender julgamentos ulteriores.

of Derecho político, Madri, 1973, p. 126, apud: ROGEIRO, O sistema constitucional da Alemanha, in:A Lei Fundamental da República Federal da Alemanha, Coimbra, Coimbra, 1996, p. 78

${ }^{65}$ ROGEIRO, op. cit., p. 78

${ }^{66}$ Não obstante a menção a Deus no preâmbulo da Lei Fundamental, entendemos tratar-se deimanência dos direitos fundamentais, e não necessariamente detranscendência - assim, v. ROGEIRO, op. cit., p. 79. Sobre a estrutura dos direitos fundamentais, analisando em especial a distinção estabelecida pelo norte-americano Ronald Dworkin entre regras e princípios, como espécies de normas jurídicas, v. ALEXY, Teoría de los derechos fundamentales, Madri, Centro de Estudios Constitucionales, 1993, p. 81 e ss.

${ }^{67}$ MENDES, Jurisdição constitucional. O controle abstrato de normas no Brasil e na Alemanha, São Paulo, Saraiva, 1996, p. 11.

Revista da Faculdade de Direito da UFRGS, v. 19, Março/200I
Concomitantemente, passa a ganhar força uma interpretação constitucionalista de todo o ordenamento jurídico ${ }^{68} \mathrm{e}$, em especial, do Direito privado ${ }^{69}$. Os juízes, imbuídos de um certo sentimento de culpa, buscam a todo custo destacar a proteção dos direitos fundamentais ${ }^{70}$, fundamentados novamente em noçōes jusnaturalistas ${ }^{71}$, após os terríveis acontecimentos gerados pela consagração do organicismo e pela ruptura totalitária na Alemanha ${ }^{72}$. Renasce, assim, em virtude da nova perspectiva proporcionada pela Lei Fundamental, o conceito jusnaturalista de pessoa, desenhando ao seu redor um "mínimo ético" 73 que não pode ser violado pelo Estado nem pelos outros membros da sociedade.

${ }^{63}$ Sobre a necessidade de preservar e fortalecer a força normativa da Constituição, arrimada no que o autor chama de "vontade de Constituição", a fim de que as questôes jurídicas (Rechtsfragen) não se tornem meras questōes de poder (Machtfragen), v. HESSE, A força normativa da Constituição, trad. por Gilmar Ferreira Mendes, Porto Alegre, Sergio Antonio Fabris, 1991, passim; o texto dessa obra baseia-se numa aula inaugural proferida por HESSE na Universidade de Freiburg em 1959, ou seja, dez anos depois da promulgação da Lei Fundamental alemã. Pregando a consideração da Constituição como efetiva fonte do Direito, o que Lei Fundamental alemã. Pregando a consideração da Constituição como efetiva fonte do Direito, o que complementa a lição de HESSE acima mencionada, v. GRIMM, La Constitución como fuente delt
in: VV.AA., Las fuentes del Derecho, Barcelona, Universidade de Barcelona, 1983, pp. 13-26.

* Quantoà umportância dos princípios constitucionais para a criaçãojurisprudencial, em especial no que se refere à tarefa de construçâo do Direito privado codificado, v a obra basilar de ESSER, Principio y norma en la elaboración jurisprudencial del Derecho privado, trad. por Eduardo Valentí Fiol, Barcelona, Bosch, 1961, pp. 88110 e 183-233.

70 HATTENHAUER, op. cit., p. 27. Em 1967, RAISER sublinhava a importância ímpar, também no âmbito específico do Direito privado, do reconhecimento de direitos e garantias fundamentais na Constituição: "Mentre Io Stato totalitario costringe ad una totale subalternità anche l'ordinamento privatistico della società, la democrazia difende le libertà e lascia spazio allo sviluppo del singolo e dei gruppi sociali. In questo quadro il diritto privato può assolvere il suo compito politico facendo valere la sua particolare tradizione, le sue istituzioni ed il suo sistema di valori" (La Costituzione e il Diritto privato, in:Il compito del Diritto privato, trad. por Marta Graziadei, Milâo, Giuffrè, 1990, p. 191).

I CS. a opiniâo de KELSEN, contrúnia ao regresso à doutrina do direito natural, que ressalta a idéia de responsabilidade dos indivíduos pelos seus própriosjuźzos de valor, pela sua escolha do que éjusto e do que é injusto O problema da justiça, trad. porJoão Baptista Machado, 3. ${ }^{\text {a }}$ ed., São Paulo, Martins Fontes, 1998, p. 114).

72 Sobre o conceito de ruptura totalitária, cunhado por Arendt v. LAFER, op. cit, passim. Já citamos o assunto (v. parte I, 2.2).

73 Segundo WELZEL (op. cit., p. 266), a expressão é de GeorgJellinek.

24 A título de registro, nos Estados Unidos da América trava-se discussão semelhante no seio da chamadastate action doctrine; sua análise, no entanto, escapa ao tema deste trabalho.

${ }^{25}$ Não podemos esquecer de mencionar, porém, as obras pioneiras de G. Dürig (Grundrechte und Zivilrechtsprechung, 1956) e de W. Leisner (Grundrechte und Privatrecht, 1960), conforme nos indica HESSE (Derecho cit., p. 31). No mesmo caminho, v. RAISER, op. cit., p. 174 e ss.; mais recentemente, retonsando o tema da Drittwirkung na Alemanha, v. CANARIS, Grundrechte und Privatrecht: eine Zwischenbilanz, Berlim/New York, Walter de Gruyter, 1999, passim.

Revista da Faculdade de Direito da UFRGS, v. 19, Março/200 
pelos particulares, e não apenas pelo Esta$\mathrm{do}^{76}$

Quanto ao Direito privado propriamente dito, o embate teórico foi além, sendo fundamental para a compreensão do seu desenvolvimento o exame da jurisprudência do BVerfG alguns casos paradigmáticos, referentes ao tema do presente trabalho, serão estudados oportunamente ${ }^{77}$. Adiantamos, porém, que a tese acolhida pelo BVerfG divergiu do entendimento antes firmado pelo Tribunal Superior do Trabalho alemão, ao optar pela eficácia mediata (mittelbare Drittwirkung) dos direitos fundamentais entre particulares, com base numa interpretação restritiva do texto do art. 1, 3, da Lei Fundamental, que assim dispõe:

"Os direitos fundamentais a seguir enunciados vinculam, como direito diretamente aplicável, os poderes legislativo, executivo e judicial." 78

De qualquer modo, dentro da visão jurídica axiológica proporcionada pelo novo ordenamento constitucional germânico, verificamos a retomada pelo Direito da noção ética de personalidade: as idéias de Gierke são trazidas novamente à baila por Heinrich Hubmann, ao publicar, em 1950, um livro chamado $O$ direito da personalidade. Apesar de tratar-se de um texto confuso, de caráter "patético-religioso" " , a concepção que ele apresenta de volta permite uma aplicação profícua das

normas constitucionais consagradoras de direitos fundamentais, como demonstrarão as decisões exaradas pelo BVerfG.

Antes de analisá-las, porém, devemos enfim situar nesse contexto a experiência constitucional brasileira, que se desenvolveu com certo atraso, ao menos nesse particular, em relação à Alemanha.

\section{Diferenças entre a experiência ale-} mã e brasileira

A primeira diferença que devemos notar entre a experiência jurídica alemã e brasileira, no que se refere à formação de uma perspectiva constitucional do Direito privado, é de ordem temporal. De fato, enquanto a Alemanha experimentou um desenvolvimento jurisprudencial muito rico desde o final da Segunda Grande Guerra, impulsionado tanto pela promulgação da Lei Fundamental de Bonn, em 1949, quanto pela instituição de uma Corte Constitucional típica, em 1951, no Brasil isso não se verificou em tais circunstâncias nem com tamanha força.

O que houve em nosso país, nesse sentido, foi a edição de uma Constituição de caráter democrático, em 18 de setembro de 1946, demarcando o fim da ditadura uni pessoal do Estado $\mathrm{Novo}^{80}$, durante o qual presidiu Getúlio Vargas, sob a égide de uma Constituição por ele outorgada (a "polaca", de 10 de novembro

${ }^{76}$ MENDES, Direitos fundamentais: eficácia das garantias constitucionais nas relaçôes privadas. Análise da jurisprudência da Corte Constitucional alemã, in:Direitos fundamentais e controle de constitucionalidade, São Paulo, IBDC/Celso Bastos, 1998, p. 217.

$\pi V$. infra, parte II, 2.1. De fato, ao analisar o ordenamento jurídico vigente na Alemanha a partir da promugacão da Lei Fundamental de 1949, sustenta HESSE que "el Tribunal Consitucional ha abierto ampliamente el Derecho privado a la influencia del Derecho constitucional" (Derecho cit., p. 59).

78 "Die nachfolgenden Grundrechte binden Gesetzgebung, vollziehende Gewalt und Rechtsprechung als unmittelbar geltendes Recht."

79 A expressão é de HATTENHAUER, op. cit., p. 27.

${ }^{\infty}$ BONA VIDES, Curso de Direito constitucional, 6. ${ }^{a}$ ed., São Paulo, Malheiros, 1996, p. 332.

Revista da Faculdade de Direito da LFRGS, v. 19, Março/2001 de 1937). Paulo Bonavides identifica na Constituição brasileira de 16 de julho de 1934, que teve curta vigência devido ao golpe de Estado em 1937, marcante influência dos rumos sociais tomados na Alemanha pela Constituição de Weimar (1919); mesmo a Constituição de 18 de setembro de 1946, ao restituir a democracia no Brasil, recebeu ainda o influxo do constitucionalismo alemão weimariano ${ }^{81}$

Não se verificou, no ordenamento constitucional brasileiro do pós-guerra, a instituição de uma Corte Constitucional propriamente dita, aos moldes do BVerfG. O tribunal maior do país continuou a ser o STF, contando com uma longa tradição a seu favor $^{82}$, mas não se configurando como órgão político responsável exclusivamente pelo controle da constitucionalidade das normas, conforme o modelo kelseniano ${ }^{23}$.

Em realidade, como ensina Gilmar erreira Mendes ${ }^{84}$, desempenha o STF uma dupla função. Se, por um lado, é responsáve pela última revisão (extraordinária stricto sensu) das decisões judiciais, faz igualmente as vezes de Corte Constitucional - mutatis mutandi, pois o sistema de controle de constitucionalidade vigente no Brasil não é concentrado, como na Alemanha. Temos, isto sim, um sistema misto, de feições próprias, uma vez que, desde 1965 , o controle incidental de constitucionalidade convive em nosso país com o controle abstrato de constitucionalidade ${ }^{85}$

Veio trazer nova luz à questão da incidência das normas constitucionais sobre o $\mathrm{D}$ militar, a promulgação da Constituição de 5 de outubro de 1988. Esta, sim, embora com certo atraso, recebeu o influxo da Lei Fundamental alemã de 1949, o que podemos perceber até mesmo na localização das normas asseguradora dos direitos e garantias fundamentais: do mesmo modo como na Lei Fundamental de Bonn, são reservados para tanto os primeiros artigos da Constituição brasileira ${ }^{86}$. Quanto ao conteúdo de tais normas, o art. 5.. , particularmente, representa uma gama de novas possibilidades para a atividade de aplicação do Direito privado brasileiro, agora sob a luz dos valores consagrados na Constituição.

A esta altura, resta citar as peculiaridades da experiência jurídica brasileira, em relação à alemã, no que se refere ao tema específico deste trabalho - i.e., o direito ao livre desenvolvimento da personalidade. No ordenamento constitucional alemão, após o dispositivo que reito privado, no Brasil, após os anos do regime

${ }^{81}$ BONAVIDES, op. cit., p. 333. Quanto à Constituição brasileira de 18 de setembro de 1946, ela não poderia ter sido influenciada pelo constitucionalismo alemão posterior à Segunda Grande Guerra, consagrado na Lei Fundamental de Bonn, porquanto esta somente foi promulgada em 23 de maio de 1949

${ }^{82}$ OSTF foi instituído no mês de janeiro de 1829, ainda nos primórdios do Império brasileiro. Retomando a história desse tribunal, v. MENDES, Jurisdição cit., pp. 23-38.

${ }^{83}$ MENDES Jurisdição cit, pp. 27-29) faz menção a uma antiga proposta de instalação de uma Corte Constitucional no Brasil, durante os trabalhos de elaboração da Constituição de 1934, abertamente inspirada no modelo pensado por Kelsen. O projeto, datado de 20 de dezembro de 1933 e feito pelo deputado Nilo Alvarenga, previa, inclusive, a adoção de uma ação popular de inconstitucionalidade, procedimento previsto por Kelsen em sua obraWesen und Entwicklung der Staatsgerichtsbarkeit (1929).

\&4 MENDES, Jurisdição cit., p. 20.

${ }^{5}$ MENDES, Jurisdição cit., $p$. 1 .

${ }^{36}$ No mesmo sentido, escreve BONA VIDES: "Na técnica, na forma e na substância da matéria pertinente a direitos fundamentais, a derradeira Constituição do Brasil se acerca da Lei Fundamental alemã de 1949, e até a ultrapassa em alguns pontos"; e adiante complementa: "Segue e incorpora também a mesma tradição de Weimar em dar preeminência ao social" (op. cit., p. 335). 
trata da proteção da dignidade da pessoa humana $^{87}, \mathrm{o}$ art. 2, 1, da Lei Fundamental estatui. "Todos têm o direito ao livre desenvolvimento da sua personalidade, desde que não violem os direitos de outrem e não atentem contra a ordem constitucional ou a lei moral." 88

O direito ao livre desenvolvimento da personalidade advém do reconhecimento doutrinário de dois princípios fundamentais que coexistem: a liberdade e a igualdade. $\mathrm{O}$ art. 2 , 1, da Lei Fundamental alemã, portanto, ao mesmo tempo em que consagra o primeiro, limita-o de acordo com o segundo. De fato, o ordenamento jurídico admite "liberdades iguais" - ou seja, liberdades individuais que não restrinjam indevidamente liberdades alheias, sob pena de tornarem-se atos de não-liberdade. Nada mais kantiano ${ }^{89}$.

$\mathrm{Na}$ Constituição brasileira, inexiste uma previsão expressa do direito ao livre desenvolvimento da personalidade. Trata-se, aqui, de princípio implícito, cuja vigência é comprovada a partir tanto da consagração da dignidade $d$ pessoa humana (art. 1., , III) quanto dos valores

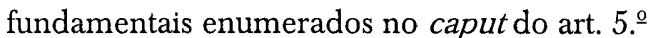
(i.e., vida, liberdade, igualdade, segurança e propriedade $)^{90}$. Uma característica própria da ordem constitucional pátria, ademais, é o rol exemplificativo apresentado nos incisos do art. 5.. , alguns dos quais exercem - ou, pelo menos, devem exercer -influência sensível na atividade de aplicação das normas de Direito privado ${ }^{91}$.

Não esqueçamos, ainda, o tratamento concedido pela atual Constituição brasileira à ordem econômica e financeira. Diz respeito fundamentalmente ao livre desenvolvimento da personalidade, sem sombra de dúvida, o texto do caput do art. 170, que assim dispõe:

"A ordem econômica, fundada na valorização do trabalho humano e na livre iniciativa, tem por fim assegurar a todos existência digna, conforme os ditames da justiça social (...)." ${ }^{92}$

Entendemos, em suma, que é a partir da composição de todas essas normas constitucionais asseguradoras de direitos e garantias fundamentais, com fulcro comum na dignidade da pessoa humana ${ }^{93}$, que se torna possível compreender o direito ao livre desenvolvimento da

${ }^{87}$ Art. 1, 1, da Lei Fundamental: "Die Würde des Menschen ist unantastbar. Sie zu achten und zu schützen ist Verpflichtung aller staatlichen Gewalt" (A dignidade da pessoa humana é inviolável. Todas as autoridades públicas têm o dever de a respeitar e proteger).

\& "Jeder hat das Recht auf die freie Entfaltung seiner Persönlichkeit, soweit er nicht die Rechte anderer verletzt und nicht gegen die verfassungsmäßige Ordnung oder das Sittengesetz verstößt” (v. supra, nota 1).

${ }^{8}$ Quanto à doutrina de Kant, v. supra (parte I, 1.2). A famosa definição kantiana do Direito apresenta-o como "o conjunto das condiçóes, por meio das quaiso arbítrio de um pode estar de acordo com o arbítrio de um outro segundo uma lei universal da liberdade " (apud: BOBBIO, Direito cit., p. 70-grifamos).

so Nesse mesmo sentido, na doutina brasileira recente, v. CORTLANO JUNIOR, Alguns apontamentos sobre os chamados direitos da personalidade, in: FACHIN (org.), Repensando fundamentos do Direito civil brasileiro contemporâneo, Rio de Janeiro, Renovar, 1998, p. 47.

${ }^{9}$ Assim, e.g., os incisos I (igualdade jurídica de homens e mulheres), II (princípio da reserva legal), IV (iberdade de manifestação do pensamento), $V$ (direito de resposta e indenização por dano material, moral ou à imagem), VT (liberdade de consciência e de crença), LX (liberdade de expressão) e X (proteçâo da intimidade e da vida privada) do art. 5. ${ }^{\circ}$ da Constituição de 1988 , num rol sem nenhuma pretensão de exauvir os vários exemplos de tal incidência.

${ }^{92}$ Grifamos.

${ }_{93}$ Quanto à dignidade da pessoa humana e sua aplicação no Direito privado, v. em especial CUNHA, op. cit., passim.

Revista da Faculdade de Direito da UFRGS, v. 19, Março/2001

personalidade como princípio geral do Direito brasileiro - embora não haja, em nossos textos legais, referência expressa ao mesmo. Afinal, como bem sustenta Eros Roberto Grau, "os princípios gerais de direito não são resgatados fora do ordenamento jurídico, porém descobertos no seu interior" 94

Desse modo, resta-nos a missão de averiguar se a jurisprudência brasileira tem ou não aplicado o direito ao livre desenvolvimento da personalidade - ainda que inconscientemente, como ratio decidendi implícita - na resolução dos casos concretos. Partindo de algumas decisões paradigmáticas das cortes superiores da Alemanha, examinaremos alguns julgados dos nossos tribunais, à procura de uma resposta à questão ora formulada, no âmbito específico dơ Direito privado.

B. Análise jurisprudencial comparativa

1. Evolução do tema na jurisprudência alemã

Antes mesmo de um pronunciamento do BVerfG, o primeiro passo rumo à recepção jurisprudencial da teoria da personalidade na Alemanha foi dado pelo Tribunal Superior de Justiça (Bundesgerichtshof - BGH), no chamado "caso do ginete": contrariando o disposto na legislação infraconstitucional e aplicando os princípios constantes da Lei Fundamental, adotou expressamente o Direito geral da personalidade para sancionar a utilização ilícita da imagem do ginete que salta a cerca, mediante reparação civil por danos ${ }^{95}$.

94 GRAU, O Direito posto e o Direito pressuposto, 2. ${ }^{\circledR}$ ed., São Paulo, Malheiros, 1998, p. 46.

${ }^{95}$ HATTENHAUER, op. cit., p. 27.

96 HATTENHAUER, op. cit., p. 27.

${ }^{97}$ BVerfGE 30, 194 e ss. - apud: HATTENHAUER, op. cit., p. 27 (traduzimos).
Realmente importante para a afirmação do Direito geral da personalidade, contudo, foi a argumentação desenvolvida pela jurisprudência germânica ao decidir o famoso "caso Mefisto". Tratava-se da proteção da imagem e personalidade do falecido Gustav Gründgens, questão que poderia ter sido resolvida, tradicionalmente, mediante a aplicação dos respectivos dispositivos de Direito penal e autoral; tanto o BGH $(250,133)$ quanto o BVerfG, porém, fundamentaram suas decisões no reconhecimento do $\mathrm{Di}$ reito geral da personalidade, chegando até a mencionar "irradiações" de uma personalidade falecida na pessoa de seus herdeiros ${ }^{96}$.

Hattenhauer critica o alcance excessivo concedido por tais decisões ao Direito geral da personalidade, uma vez que parece supor como certa uma segunda vida dos seres humanos após a morte, conforme demonstram julgados como o seguinte:

"Resultaria inconciliável com o preceito constitucional da inviolabilidade da dignidade humana (...) que o homem, a que corresponde dita dignidade por ser pessoa pudesse quedar dela despossuído, ou vexado em sua consideração depois da morte. ${ }^{97}$

Com efeito, é plausivel questionarmos o acerto de tal posicionamento teórico, porquanto sabemos que o conceito jurídico de pessoa parte da existência de vida humana; conceber efeitos da personalidade de alguém que já não vive é, no mínimo, um entendimento discutível. Assim sendo, a jurisprudência do BVerfG se preocupou, cada vez mais, com a necessidade de estabelecer critérios supostamente seguros

Revista da Faculdade de Direito da UFRGS, v. 19, Março/2001 
para fazer face à argumentação jurídica por princípios.

Nesse sentido, são marcantes as decisões de casos como o do "assassinato de soldados em Lebach", documentário da rede televisiva alemã ZDF que mencionava expressamente nome das pessoas acusadas de cumplicidade no referido crime. Robert Alexy, ao versar sobre a estrutura dos direitos fundamentais, desenvolve a noção de ponderação a partir de um exame do julgamento desse caso $^{98}$, como solução de uma colisão de princípios constitucionais. De fato, o BVerfG identificou de modo expresso "uma situação de tensão entre a proteção da personalidade, garantida no art. 2, 2, em conexão com o art. 1, 1, da Lei Fundamental, e a liberdade de informação de acordo com $o$ art $5,1,2$, da Lei Fundamental" ${ }^{99}$; num segundo momento, o tribunal declarou que nenhuma das normas aludidas era inválida, nenhuma delas tinha precedência absoluta, dependendo predomínio de uma ou outra em relação às circunstâncias concretas do caso.

Alexy sustenta, a partir daí, a existência de peculiaridades inerentes ao raciocínio judicial utilizado na aplicação dos princípios juríd

9 BverfGE 35, 202 e ss. - apud: ALEXY, op. cit., pp. 95 e ss.

so BverfGE 35, 202 (219).

100 ALEXY, op. cit., pp. 96 e ss.

${ }^{101}$ Nesse sentido, a obra já clássica de VIEHWEG, Tópica y jurisprudencia, trad. por Luis Díez-Picazo Ponce de León, Madri, Taurus, 1986, passim, cuja primeira ediçẫo alemã data de 1963.

${ }_{102} V$. supra (parte II, 1.2).

${ }^{103}$ MENDES (Direitos cit., pp. 220-222) cita ainda outras três decisōes paradigmáticas do BVerfG quanto ao reconhecimento da efcácia dos direitos fundamentais nas relaçóes privadas: o "caso Lüth" (BVerfGE 7, 198), o "caso Blinkfüer" (BVerfGE 25, 256) e o "caso Wallraff" (BVerfGE 66, 116).

${ }^{10 *}$ CANARIS, op. cit., p. 96. O jurista alemão reconhece diferenças entre a eficácia dos direitos fundamentais sobre as leis de Direito privado (a), na atividade de aplicação e aperfeiçoamento judicial do Direito privado (b) e nas condutas dos sujeitos privados (c). Desse modo nos casos (a) a (b) haveria indubitaveluent eficácia imediata (unmittelbare Drittwirkung) dos direitos fundamentais, enquanto no caso (c) sua eficácia seria meramente mediata (mittelbare Drittwirkung), exercendo os direitos fundamentais, aí, a função de postulado de proteção (Schutzgebotsfunktion). No mesmo sentido, examinando a jurisprudência alemã e também citando idéias desenvolvidas por Canaris, v. MENDES, Direitos cit., pp. 216-217.

Revista da Faculdade de Direito da UFRGS, v. 19, Março/2001 do a uma maior justeza das decisões judiciais. Então perguntamos: e no Brasil?

2. Alcance da expressão na jurisprudên cia brasileira

O direito ao livre desenvolvimento da personalidade, ja aduzimos, situa-se entre os princípios fundamentais do Direito brasileiro ${ }^{105}$, tend especialissima relevância no âmbito jusprivado. Tanto é assim que, de acordo com Konrad Hesse, tarefa central do Direito privado atualmente se constitui na defesa do Direito da personalidade, entendido tanto em seu aspecto negativo (intimidade) quanto em seu aspecto positivo (autonomia privada): resgataria, desse modo, seu caráter de "baluarte da liberdade" 106

A jurisprudência pátria, contudo, parece não ter descoberto todas as potencialidade desse princípio implícito de nosso sistema jurídico, como tampouco o fez em relação ao princí pio expresso da dignidade da pessoa humana (art. 1.ำ, III, da Constituição). Em grande parte das decisões de nossos tribunais, verificamos que permanece vigente a noção arcaica de que somente o Código Civil - e não a Constituição se aplica ao Direito privado, representando a perspectiva constitucional, nesse particular, uma corrente francamente minoritária.

Ao pesquisarmos os julgados de nossa corte mais alta, p.ex., constatamos com pesa que as únicas menções ao termo "personalida de" se referem não aos valores que se irradiam da pessoa humana, mas à personalidade jurídica stricto sensu ou ficta. Ou seja, discute-se an tes a natureza das pessoas jurídicas, se de direito público ou privado, sem que se adentre o tema

${ }^{105}$ V. supra (parte II, 1.2).

${ }^{106}$ HESSE, Derecho cit., p. 74

${ }^{107}$ RE 16.934, STF, 2. Turma, rel. Min. Orosimbo Nonato, j. em 02.01.1951, DJ de 13.09.1951. ${ }^{108}$ RE 100.094/PR, STF, 1. I. Turma, rel. Min. Rafael Mayer, j. em 28.06.1984, DJ de 24.08.1984. muito mais adequado à missão de uma Corte Constitucional, ao nosso ver, que é o direito ao livre desenvolvimento da personalidade.

Causa semelhante estranheza percebermos que as duas exceções encontradas na jurisprudência do STF à regra acima mencionada pertencem ao período anterior à promulgação da atual Constituição, em condições que, como é notório, se prestavam menos a uma aplicação dos princípios constitucionais nas relaçōes de Direito privado. A primeira de tais decisões data de 2 de janeiro de 1951, tendo como relator o Min. Orosimbo Nonato, que reconheceu a inalienabilidade dos direitos de personalidade envolvidos num caso específico de fiança sem outorga uxória ${ }^{107}$; o segundo julgamento deuse em 28 de junho de 1984, resultando na seguinte ementa:

"Direito ao recato ou à intimidade. Garantia constitucional. Interceptação de comunicação telefônica. Captação ilegítima de meio de prova. Art. 153, § 9.ํ, da Constituição. Art. 332 do Código de Processo Civil.

Infringente da garantia constitucional do direito da personalidade, moralmente ilegítimo é o processo de captação de prova, mediante a interceptação de telefonema, à revelia do comunicante, sendo, portanto, inadmissível venha a ser divulgada em audiência de processo judicial, de que sequer é parte. (...)" 108

Não obstante terem tais julgados assinalado a fundamental relevância dos direitos da personalidade, destacando-se dentre a maioria das decisões do STF em soluções de casos similares, é ainda notável a distância que os separa

Revista da Faculdade de Direito da UFRGS, v. 19, Març/2001 
do alcance efetivo da teoria inaugurada por Gierke e desenvolvida pelos tribunais alemães. Encontra-se mais próxima do modelo descrito neste trabalho, em compensação, a jurisprudên cia do STJ, tendo a seu favor a égide da Cons tituição de 1988. Menções aos direitos da personalidade são, nos julgados dessa Corte, consideravelmente mais freqüentes, indicando uma linha de pensamento mais arejada em relação aos valores constitucionais - embora tais referências estejam, na maior parte das vezes, ligadas tão-somente a duas espécies de casos: por um lado, à proteção dos direitos autorais ${ }^{109}$; por outro, à violação da honra ou da imagem pela imprensa $^{110}$

Assim sendo, por enquanto não podemos falar no reconhecimento integral de un Direito geral da personalidade pelos nossos tribunais superiores.

No entanto, se deixarmos o âmbito das Cortes federais e focalizarmos a atenção na ju-

risprudência de alguns tribunais estaduais, o quadro hermenêutico parece revelar maior riqueza. Nosso campo de estudo restringiu-se a algumas decisões do TJRS, que leva consigo a tradição de ser um pretório com notável força criadora dentro do Brasil, e o resultado obtido foi, em nossa análise, realmente mais proficuo. Isso se deve a duas razões princi pais:

a) em primeiro lugar, a perspectiva constitucional do Direito privado resta reconhecida em vários acórdãos - seja em relação à proteção da imagem e da honra pessoais, fazendo-se menção expressa ao art. $5 .^{.}, \mathrm{X}$, da Constituição $^{111}$, seja quando se identifica a existência de uma tensão entre princípios constitucionais díspares, partindo-se para uma solução do litígio que atente às peculiaridades do caso concreto $^{112}$. Essa percepção de um conflito entre normas jurídicas igualmente válidas e da necessidade de uma resolução casuística, por assim dizer, representa uma inegável conquista em relação à jurisprudência dominante no resto do país;

${ }^{100}$ Os direitos autorais, de fato, representam historicamente uma área pioneira de atenção aos direitos da Os direltos aultoras, de fro, in

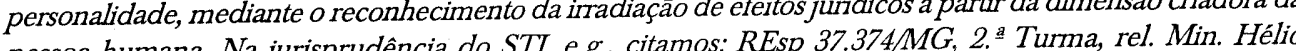
pessoa humana. Na jurisprudência do ST, e.g., citamos. REsp J7.J74/MG, 2. Turma, Tel. Min. Hello Mosimann, j. em 28.09.1994, DJ de 24.10.1994, RSTJ 67 DI7, RE Sálvio de Figueiredo Teixeira, j. em 23.02.1999, DJ de 21.06.1999, RSTJ 122/302 ("caso Garnincha") REsp 45.305,SP, 4." Turma, rel. Min. Sálvio de Figueiredo Teixeira, J. em 02.09.1999, DJ de 25.10.1999,

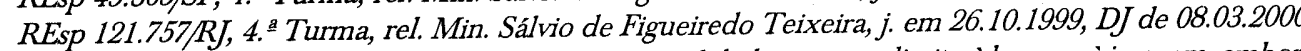

${ }^{11}$ Quanto à violação pela imprensa de direitos da personalidade, como o direito à honra e à imagem, embor haja dispositivo constitucional específico de tutela (art. $5 ., \frac{\circ}{X}$, da Constituição), não são todos os acórdâos que partem dessa perspectiva. Sem mencionar a Constituição, citamos: REsp 58.101/SP, STJ, 4. ${ }^{a}$ Turma, rel. Min. César Asfor Rocha, j. em 16.09.1997, DJ de 09.03.1998, RSTJ 104/326; REsp 109.470/PR, STJ, 3. ." Turma, rel Min. Carlos Alberto Menezes Direito, j. em 15.12.1997, DJ de 21.06.1999; REsp 192.786/RS, STJ 3 a Torma rel. Min. Nilson Naves, j. em 23.11.1999, DJ de 27.03.2000. Por outro lado, alegando STJ, 3. Turma, rel. Min. Nilon Naves, J. em 23.11. Le Do 5.350/67 (Lei de Imprensa), citamos: REsp violaçấo do art. 5., X, da Constituiçâo pelo art. S2 da Lei 85.019/RJ, STJ, 4. Turma, rel. Min. Salvio de Figueiredo Teix Tira, 5. Câm. Cível, rel. Des. Clarindo "II Assim, p.ex., o julgamento da AC 598.532.414, Porto Alegre, TJRS, 5. ․ Câm. Cível, rel. Des. Clarindo
Favretto, j. em 23.09.1999.

II2 É o que ocorre, e.g., nos seguintes acórdãos: AC 596.142.562, Canoas, TJRS, 5. " Câm. Civel, rel. Des. Araken de Assis, j. em 22.08.1996; AC 597.035.849, Arroio do Meio, TJRS, 5." Câm. Cível, rel. Des. Araken de Assis, j. em 27.03.1997. En ambos os exemplos, a tensão identificada pelo Des. Araken de Assis deu-se entre o direito à honra e à imagem (art. 5., $\mathrm{VeX}$, da Constituição) e o direito à liberdade de expressão e crítica (art 5. o IV, da Constituição). Como vimos, segundo Alexy (v. parte II, 2.1), deve-se empreender e cres direitos e garantias fundamentais em aparente conflito, a fim de averiguar qual prevalecerá no caso concreto.

Revista da Faculdade de Direito da UFRGS, v. 19, Março/2001 b) em segundo lugar, o alcance concedido aos direitos da personalidade é bastante mais lato $^{113}$, não se limitando à proteção dos direitos autorais, da imagem ou da honra, como é de praxe. Certamente, o poder criador mais acentuado que costuma caracterizar a jurisprudência do TJRS tem papel importante nessa atividade hermenêutica de reconhecimento das mais variadas manifestações do Direito da personalidade, em especial no âmbito jusprivado.

Essa nova visão jurisprudencial, enfim, atenta à consagração constitucional da dignidade da pessoa humana (art. 1.., III, da Constituição) e à plena vigência, como princípio fundamental implícito do sistema jurídico brasileiro, possuidor de formidável força valorativa, do direito ao livre desenvolvimento da personalidade, atinge o seu auge com a seguinte decisão proferida no seio do nosso TJRS, ao julgar um pedido de retificação de registro civil feito por uma pessoa transexual:

"É preciso, inicialmente, dizer que homem e mulher pertencem à raça humana. Ninguém é superior. Sexo é uma contingência.
Discriminar um homem é tão abominável como odiar um negro, um judeu, um palestino, um alemão ou um homossexual. As opções de cada pessoa, principalmente no campo sexual, hão de ser respeitadas, desde

O direito à identidade pessoal é um dos direitos fundamentais da pessoa humana. A identidade pessoal e a maneira de ser, como a pessoa se realiza em sociedade, com seus atributo com sua bagagem cultural e ideológica, é o direito que tem todo o sujeito de ser ele mesmo. A identidade sexual, considerada como um do aspectos mais importantes e complexos compreendidos dentro da identidade pessoal, forma-se em estreita conexão com uma pluralidade de direitos, como são aqueles atinentes ao livre desenvolvimento da personalidade, etc.

Para dizer assim, ao final: se bem que não é ampla nem rica a doutrina jurídica sobre o particular, é possível comprovar que a temática não tem sido alienada para o Direito vivo, quer dizer, para a jurisprudência comparada. Com efeito, em Direito vivo, tem sido buscado e que não façam mal a terceiros. e defeitos, com suas características e aspirações,

${ }^{113}$ De fato, os direitos da personalidade são utilizados como fundamento decisório em casos tão distintos quanto: invalidade de cláusula, em contrato de seguro-saúde, que exclui da cobertura certo tratamento experimental, sendo a beneficiária portadora de câncer em estado terminal, devido ao reconhecimento do caráter absoluto do direito à vida (AC 595.161.639, Porto Alegre, TJRS, 2. ${ }^{\circ}$ Grupo de Câm. Cíveis, rel. Des. Tael João Selistre, j. em 15.12.1995); ilicitude do cadastramento do cliente bancário em razão da devolução de cheque com fundos suficientes (AC 597.113 .257 , Porto Alegre, TJRS, $5^{3}$ Câm. Civel rel Des. Araken de Assis, de neg ir Des. Araken de Assis, j. em 07.08.1997); ilicitude de atos administrativos emitidos pelo Município sem motivação suficiente, aparentemente em perseguição a empregado público (AC 597.082.890, Erexim,

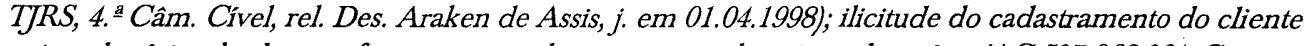
cujos talonários de cheques foram extraviados no interior da agência bancária (AC 597.068.964, Canoas,

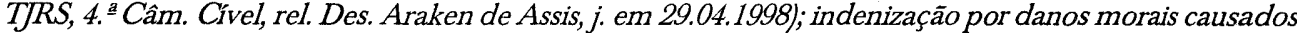
pelo fornecimento de produto impróprio ao consumo humano, bem como por danos à saúde oriundos da

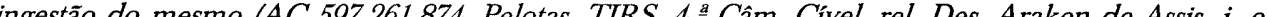
13.05.1998), invalidade de transferência do aluno que, após dois anos de eletuva adaptação, freqüenta regularmente determinada escola de ensino público fundamental, em atenção às normas protetivas do menor (AC 599.102.977, Santa Cruz do Sul, TJRS, 4. " Câm. Cível, rel. Des. Vasco della Giustina, j. em 05.05.1999). 
correspondido e atendido pelos juízes, na falta de disposições legais e expressa. No Brasil, aí está 0 art. 4.ำ da Lei de Introducão ao Código Civil, a permitir a equiidade e a busca da Justica.

Por esses motivos, é de ser deferido o pedido de retificação do registro civil para alteração de nome e de sexo." 114

A constatação dessa referência expressa ao direito ao livre desenvolvimento da personalidade, com argumentos de inspiração kantiana ${ }^{115}$, tão rara em nosso cotidiano judici$a^{116}$, vem justamente reforçar a tese ora defendida, comprovando que não tentamos, nestas páginas, realizar mera e desatenta importação de uma teoria alienígena para o Direito brasileiro. Tratamos, isto sim, de um princípio que vige em nosso ordenamento jurídico, embora submerso em seu interior: ele apenas aguarda, nos termos utilizados por Grau, ser integralmente descoberto ${ }^{117}$.

\section{CONCLUSÕES}

Com base no exposto, as teses cuja veracidade tentamos demonstrar, em síntese, são as seguintes:

a) A noção de personalidade não tem raiz idêntica ao conceito jurídico de pessoa. Enquanto este tem origem remota e experimentou

um longo e inconstante processo de desen volvimento histórico, a personalidade nasceu como uma definição essencialmente ética e foi, num momento posterior, recepcionada e adequada pela ciência do Direito;

b) Nesse sentido, sob o influxo racionalista das idéias iluministas, a laicização da personalidade representou uma notável conquista da doutrina jurídica, tendo como fecho teórico a vinculação da liberdade humana à Moral empreendida de forma definitiva por Kant;

Nos últimos anos do século XIX, seguindo corrente distinta daquela assumida pela Pandectística alemã, ganha destaque a obra pioneira de Gierke, mormente no que diz respeito ao desenvolvimento teórico do $\mathrm{Di}$ reito geral da personalidade, ainda que não bem acabado;

d) O período de ascensão ao poder do nacional-socialismo, entendido como ruptura totalitária, ao celebrar o organicismo e apagar, assim, todos os paradigmas até então vigentes no que se refere aos direitos e garantias fundamentais, enviou ao limbo a teoria da personalidade, com conseqüências funestas;

e) Com o fim da Segunda Grande Guerra, a Alemanha empreende uma retomada coletiva da sua tradição ética, o que gera reflexos notáveis no âmbito jurídico, principalmente a partir da promulgação da Lei Fundamental e da instituição do BVerfG, a de-

IIt AC 593.110.547, Porto Alegre, TJRS, 3. ํ. Câm. Cível, rel. Des. Luiz Gonzaga Pilla Hofmeister, j. em 10.03.1994 (grifamos)

115 É certo que a inspiração das idéias de Kant, no acórdão acima transcrito, pode não ter sido conscientemente arquitetada. Resta clara, não obstante, a coincidência de propósitos em passagens como: "As opçōes de cada pessoa (...) hão de ser respeitadas, desde que não façam mal a terceiros". A noção que se apresenta, em suma nada mais é do que a consagração de liberdades iguais - ou seja, de liberdades que não atentem às liberdades dos outros, a fim de não se transformarem, aquelas, em não-liberdades (sobre esse aspecto particular do pensamento kantiano, v. BOBBIO, Direito cit., p. 71).

${ }^{116}$ Sobre o predomínio de uma concep̧̧ão hobbesiana de "pessoa" no STF, com ênfase na suafunção, em cotejo com o primado notoriamente kantiano no BVerfG, conforme já aludimos, v. o instigante ensaio de ALVES Dignidade da pessoa, do sujeito ou da personalidade?, Porto Alegre, inédito, 2000.

IIt GRAU, op. cit, p. 46

Revista da Faculdade de Direito da UFRGS, v. 19, Março/2001 marcar uma renovada perspectiva axiológica do Direito privado, com base constitucional;

f) No Brasil, devido às peculiaridades que caracterizaram nossa experiência jurídica, um alcance similar ao formulado pela Lei Fundamental alemã só veio a ocorrer mais recentemente, com a promulgação da Constituição de 1988 e a superação democrática do período ditatorial militar;

g) Partindo de dispositivos constitucionais expressos, a jurisprudência alemã moldou tanto o direito expresso ao livre desenvolvimento da personalidade quanto o princípio da dignidade da pessoa humana - que se apresenta como fundamento último daquele direito;

h) No caso do Brasil, o direito ao livre desenvolvimento da personalidade é princípio que tem pleno vigor em nosso sistema jurídico, ainda que de modo implícito, e embasa tanto a proteção da intimidade quanto o reconhecimento e preservação da autonomia privada, sendo tarefa da jurisprudência descobrir e trabalhar todas as suas potencialidades.

\section{OBRAS CONSULTADAS}

ALEXY, Robert. Sistema jurídico, princi pios jurídicos y razón práctica. In: Derecho y razón práctica. 2. ed. México: Fontamara, 1998. (pp. 7-20) fundamentales. Trad. espanhola. Madri Centro de Estudios Constitucionales, 1993.

ALVES, Gláucia Correa R. Barcelos. Dignidade da pessoa, do sujeito ou da personalidade? Trabalho apresentado na disci plina de Teoria Geral do Direito Privado do PPGD/ UFRGS. Porto Alegre : inédito, 2000.

ARENDT, Hannah. Eichmann em Jerusalém. Um relato sobre a banalidade do mal. Trad. por José Rubens Siqueira. São Paulo : Companhia das Letras, 1999.
ÁVILA, Humberto Bergmann. A distinção entre princípios e regras e a redefinição do dever de proporcionalidade. Revista de Direito Administrativo, vol. 215. Rio de Janeiro : jan.-mar. 1999. (pp. 151-179)

BOBBIO, Norberto. Direito e Estado no pensamento de Emanuel Kant. Trad. por Alfredo Fait. 4. ${ }^{\mathrm{a}}$ ed. Brasília : Universidade de Brasília, 1997.

Kant e a Revolução Francesa. In: A era dos direitos. Trad. por Carlos Nelson Coutinho. Rio de Janeiro : Campus, 1992. (pp. 131-141)

BONAVIDES, Paulo. Curso de Direito constitucional. 6. ed. São Paulo : Malheiros, 1996.

CAMPOS, Diogo Leite de. Lições de direitos da personalidade. 2.. $\mathrm{a}$ ed. Coimbra : Universidade de Coimbra, 1995

CANARIS, Claus-Wilhelm. Grundrechte und Privatrecht: eine Zwischenbilanz. Berlim/ New York : Walter de Gruyter, 1999.

CORTIANO JUNIOR, Eroulths. Alguns apontamentos sobre os chamados direitos da personalidade. In: FACHIN, Luiz Edson (org.). Repensando fundamentos do Direito civil brasileiro contemporâneo. Rio de Janeiro : Renovar, 1998. (p. 31-56)

CUNHA, Alexandre dos Santos. Dignidade da pessoa humana: conceito fundamental do Direito civil. Trabalho apresentado na disciplina de Teoria Geral do Direito Privado do PPGD/UFRGS. Porto Alegre : inédito, 1999.

DOCUMENTÁRIO. Hitlers Helfer: Freisler der Hinrichter. Vídeo legendado. $60 \mathrm{~min}$. Alemanha : ZDF, 1998.

EDELMAN, Bernard. La personne en danger Paris : Presses Universitaires de France, 1999

ESSER, Josef. Principio y norma en la elaboración jurisprudencial del Derecho privado. Trad. por Eduardo Valentí Fiol. Barcelona: Bosch, 1961. 
GIERKE, Otto von La función social del Derecho privado/La naturaleza de las asociaciones humanas. Trad. por José M. Navarro de Palencia. Madri : Sociedad Editorial Española, 1904.

GRAU, Eros Roberto. O Direito posto e o Direito pressuposto. 2." ed. São Paulo: Malheiros, 1998.

GRIMM, Dieter. La Constitución como fuente del Derecho. In: VV.AA. Las fuentes deI Derecho. Trad. espanhola. Barcelona : Universidade de Barcelona, 1983. (pp. 13-26)

HATTENHAUER, Hans. Conceptos fundamentales del Derecho civil. Introducción histórico-dogmática. Trad. por Gonzalo Hernández. Barcelona : Ariel, 1987.

HESPANHA, António Manuel. Panorama histórico da cultura jurídica europeia. 2. ${ }^{\mathrm{a}} \mathrm{ed}$. S/1 : Europa-América, 1998

HESSE, Konrad. $A$ força normativa da Constituição. Trad. por Gilmar Ferreira Mendes. Porto Alegre : Sergio Antonio Fabris, 1991.

Derecho constitucional y Derecho privado. Trad. por Ignacio Gutiérrez-Gutiérrez. Madri : Civitas, 1995.

IMAZ, Eugenio. Prólogo. In: KANT, Immanuel. Filosofia de la História. Trad. por Eugenio Imaz. 1. ${ }^{a}$ ed. México : Fondo de Cultura Económica, 1941. (pp. 1-23)

KANT, Immanuel. A religião dentro dos limites da simples razão. Trad. por Tania Maria Bernkopf. In: Os pensadores: Kant. 1. ${ }^{\mathrm{a}}$ ed. São Paulo : Abril Cultural, 1974. (pp. 365São Paulo : Abril Cultural, 1974. (pp. 365-
389)

Crítica da razão prática.

Trad. por Artur Morão. Lisboa : Edições 70, 1997

Fundamentação da

Metafisica dos costumes. Trad. por Paulo Quintela. In: Os pensadores: Kant. $1 .^{\mathrm{a}} \mathrm{ed}$. São Paulo : Abril Cultural, 1974. (pp. 195256)
· ¿Qué es la ilustración? In: Filosofia de la História. Trad. por Eugenio Imaz. 1. ${ }^{a}$ ed. México : Fondo de Cultura Económica, 1941. (pp. 25-38)

KASER, Max. Direito privado romano. Trad. por Samuel Rodrigues e Ferdinand Hämmerle. Lisboa : Fundação Calouste Gulbenkian, 1999.

Römisches Privatrecht. 5

ed. Munique/Berlim : C. H. Beck, 1966

KELSEN, Hans. O problema da justiça. Trad. por João Baptista Machado. 3. ㄹ ed. São Paulo : Martins Fontes, 1998

Teoria geral do Direito

do Estado. Trad. por Luís Carlos Borges. 3. ed. São Paulo : Martins Fontes, 1998.

Teoria pura do Direito.

Trad. por João Baptista Machado. 4. a ed São Paulo : Martins Fontes, 1995.

LAFER, Celso. A reconstrução dos direitos humanos. Um diálogo com o pensamento de Hannah Arendt. São Paulo : Companhia das Letras, 1999

LARENZ, Karl. Derecho civil: Parte general Trad. por Miguel Izquierdo e Macías-Picavea. Madri : Revista de Derecho Privado, 1978. Derecho justo. Fundamen tos de Etica jurídica. Trad. por Luis Díez Picazo. Madri : Civitas, 1993.

LA TORRE, Massimo. La "lotta contro il diritto soggettivo". Karl Larenz e la dottrina giuridica nazionalsocialista. Milão : Giuffrè, 1988.

MACHADO DE ASSIS, Joaquim Maria. Obra completa. Rio de Janeiro :José Aguilar, 1959. (vol. II)

MENDES, Gilmar Ferreira. Direitos fundamentais: eficácia das garantias constitucionais nas relações privadas. Análise da jurisprudência da Corte Constitucional alemã. In: Direitos fundamentais $e$ controle de constitucionalidade. São Paulo : IBDC/Celso Bastos, 1998. (pp. 207-225)
Jurisdição constitucional. O controle abstrato de normas no Brasil e na Alemanha. São Paulo : Saraiva, 1996.

OPPETIT, Bruno. Philosophie du Droit. Paris : Dalloz, 1999.

PONTES DE MIRANDA, Francisco Cavalcanti. Tratado de Direito privado. 2. ${ }^{\mathrm{a}}$ ed. Rio de Janeiro : Borsoi, 1954-66. (t. I, VII e LIII)

RADBRUCH, Gustav. Cinco minutos de Filosofia do Direito. In: Filosofia do Direito Trad. por L. Cabral de Moncada. 6..$^{\mathrm{a}}$ ed. Coimbra : Arménio Amado, 1997. (pp. 415 418)

RAISER, Ludwig. La Costituzione e il Diritto privato. In: Il compito del Diritto privato. Trad. por Marta Graziadei. Milão : Giuffrè, 1990. (pp. 169-191)

REALE, Miguel. Ciência do Direito e dialética. In: Horizontes do Direito e da História. 3 ed. São Paulo : Saraiva, 2000. (pp. 343-348) Direito e Cultura. In: rizontes dó Direito e da História. 3. $\mathrm{a}$ ed. São Paulo : Saraiva, 2000. (pp. 292-296)
Filosofia do Direito. 17.. ed. São Paulo : Saraiva, 1996.

ROGEIRO, Nuno. O sistema constitucional da Alemanha. In: $A$ Lei Fundamental da República Federal da Alemanha. Coimbra : Coimbra, 1996. (pp. 13-102)

SALGADO MARTINS, José. Preparação à Filosofia. 3. ${ }^{\mathrm{a}}$ ed. Porto Alegre : Globo, 1978.

VIEHWEG, Theodor. Tópica y jurisprudencia. Trad. por Luis Díez-Picazo Ponce de León. Madri : Taurus, 1986.

WELZEL, Hans. Introducción a la Filosofia del Derecho. Derecho natural y justicia material. Trad. por Felipe González Vicén. Madri : Aguilar, 1971.

WIEACKER, Franz. História do Direito privado moderno. Trad. por A. M. Botelho Hespanha. 2. ${ }^{a}$ ed. Lisboa : Fundação Calouste Gulbenkian, 1993. 